\title{
Mapping freeze/thaw boundaries with SMMR data $^{1}$
}

\author{
B.W. Zuerndorfer, A.W. England, M.C. Dobson and F.T. Ulaby \\ Radiation Laboratory, Department of Electrical Engineering and Computer Science, The University \\ of Michigan, Ann Arbor, MI 48109-2122 (U.S.A.)
}

(Received July 3, 1989; revision accepted December 12, 1989)

\begin{abstract}
Zuerndorfer, B.W., England, A.W., Dobson, M.C. and Ulaby, F.T., 1990. Mapping freeze/thaw boundaries with SMMR data. Agric. For. Meteorol., 52: 199-225.

Nimbus 7 SMMR data are used to map daily freeze/thaw patterns in the upper Midwest for the fall of 1984. The combination of a low $37 \mathrm{GHz}$ radiobrightness and a negative $10.7,18$ and $37 \mathrm{GHz}$ spectral gradient, $\partial T_{\mathrm{b}} / \partial f$, appears to be an effective discriminant for classifying soil as frozen or thawed. The $37 \mathrm{GHz}$ emissivity is less sensitive to soil moisture than are the lower frequency emissivities so that the $37 \mathrm{GHz}$ radiobrightness appears to track soil surface temperature relatively well. The negative gradient for frozen ground is a consequence of volume scatter darkening at shorter microwave wavelengths. This shorter wavelength darkening is not seen in thawed moist soils.
\end{abstract}

\section{INTRODUCTION}

Soil moisture contributes to the energy exchange between the air and ground through latent heats of fusion and vaporization. Whether as boundary conditions for mesoscale climate modelling, or as inputs to an agricultural productivity model, the amount and state of soil moisture are regional parameters that one would like to estimate through satellite remote sensing. There is a large body of literature that addresses the estimation of soil moisture from remotely sensed radiobrightness (e.g. Burke et al., 1979; Wang et al., 1982; Schmugge, 1983; Camillo and Schmugge, 1984; Schmugge et al., 1986; Schmugge, 1987; Grody, 1988). We present evidence that moisture state can also be inferred from radiobrightness.

Freezing influences the measured radiobrightness temperature of the ground, $T_{\mathrm{b}}$, through parameters in the approximation (Ulaby et al., 1981), $T_{\mathrm{b}}=e T_{\mathrm{o}}+(1-e) T_{\text {sky }}$

'This work was supported by the Shell Oil Company Foundation and the NASA Interdisciplinary Research Program under grant NAG5-852. 
where $e$ and $T_{\mathrm{o}}$ are the emissivity and surface temperature of the ground, respectively, and $T_{\text {sky }}$ is the effective sky brightness. For this study, we are able to ignore atmospheric emission and absorption by limiting observation to clear days, and by employing frequencies that are distant from the $22 \mathrm{GHz}$, atmospheric $\mathrm{H}_{2} \mathrm{O}$ band. Frozen ground exhibits signatures of: (1) lower thermal temperatures, $T_{\mathrm{o}}$; (2) higher emissivity, $e$, and, as we will demonstrate; (3) a decrease in brightness temperatures with microwave frequency;

$\frac{\partial T_{\mathrm{b}}}{\partial f}<0$

Signatures (1) and (2) are frequently ambiguous indicators of frozen ground because the changes in radiobrightness that result from freezing may be either positive or negative, depending upon the soil moisture content. Water molecules in frozen plants and soils are not free to align themselves with microwave electric fields. This constraint upon the rotational freedom of water gives rise to an apparent dryness to microwaves. The consequence is a decrease in the real part of the dielectric constant, $\epsilon^{\prime}$, and an increase in frozen soil emissivity. For example, the real part of dielectric constants, $\epsilon^{\prime}$, and corresponding emissivities at nadir, $\epsilon(0)$, of two, homogeneous, smooth surfaced, $15 \%$ moist soils at $10 \mathrm{GHz}$ are shown in Table $1 \mathrm{a}$. Because of increasing emissivity with freezing, a $10^{\circ}$ decrease in the clay and silt soil temperatures, from $+5^{\circ} \mathrm{C}$ to $-5^{\circ} \mathrm{C}$, would cause an increase in $T_{\mathrm{b}}$ of approximately +14 $\mathrm{K}$ and $+28 \mathrm{~K}$, respectively. The positive direction of change in $T_{\mathrm{b}}$ with soil freezing will cause confusion in discrimination between moist soils which will appear radiometrically warmer when frozen (due to emissivity increase), and

TABLE 1

Radiometric properties of soils (Hoekstra and Delaney, 1974)

(a) Nadir brightness temperatures

\begin{tabular}{|c|c|c|c|c|c|c|}
\hline \multirow[t]{2}{*}{ Material } & \multicolumn{3}{|c|}{$+5^{\circ} \mathrm{C}$} & \multicolumn{3}{|c|}{$-5^{\circ} \mathrm{C}$} \\
\hline & $\epsilon^{\prime}$ & $e(0)$ & $T_{\mathrm{b}}$ & $\epsilon^{\prime}$ & $e(0)$ & $T_{\mathrm{b}}$ \\
\hline Goodrich Clay & 8.2 & 0.77 & 221 & 4.9 & 0.86 & 235 \\
\hline Fairbanks Silt & 9.6 & 0.74 & 214 & 4.1 & 0.89 & 242 \\
\hline
\end{tabular}

(b) Effective emission depths

\begin{tabular}{|c|c|c|c|c|c|c|c|c|}
\hline \multirow[t]{2}{*}{ Material } & \multicolumn{4}{|c|}{$+5^{\circ} \mathrm{C}$} & \multicolumn{4}{|c|}{$-5^{\circ} \mathrm{C}$} \\
\hline & $\epsilon^{\prime}$ & $\epsilon^{\prime \prime}$ & $\tan \delta$ & $z_{\mathrm{e}}$ & $\epsilon^{\prime}$ & $\epsilon^{\prime \prime}$ & $\tan \delta$ & $z_{\mathrm{e}}$ \\
\hline Goodrich Clay & 8.2 & 3.5 & 0.43 & $0.13 \lambda_{0}$ & 4.9 & 1.0 & 0.20 & $0.36 \lambda_{0}$ \\
\hline Fairbanks Silt & 9.6 & 5.0 & 0.52 & $0.10 \lambda_{\mathrm{o}}$ & 4.1 & 0.02 & 0.005 & $15.7 \lambda_{0}$ \\
\hline
\end{tabular}


dry soils which undergo little molecular change and will appear radiometrically colder (due to temperature decrease).

The shift in emissivity with freezing is most pronounced at the lower microwave frequencies. At $37 \mathrm{GHz}$, the effect is reduced but not absent. We observe that the $37 \mathrm{GHz}$ radiobrightness correlates relatively well with air temperature (Fig. 1). Since soil surface temperature should follow the air temperature, the $37 \mathrm{GHz}$ radiobrightness can be expected to provide a reasonably reliable estimate of soil surface temperature. However, discrimination based only on the $37 \mathrm{GHz}$ radiobrightness would misclassify too often.

Our data suggest a third signature of frozen soil. Freezing reduces the imaginary part of the dielectric constant, $\epsilon^{\prime \prime}$, proportionally more than it does the real part, $\epsilon^{\prime}$. The loss tangent, $\tan \delta=\epsilon^{\prime \prime} / \epsilon^{\prime}$, is a measure of the attenuation per microwave wavelength. Reduced loss tangent, or lower attenuation, means that thermally emitted photons originate deeper within emitting media. That is, the effective depth of emission, $z_{\mathrm{e}},\left(1-e^{-1}\right.$ of the emission originates above $z_{\mathrm{e}}$ ) becomes a larger fraction of the free-space wavelength, $\lambda_{\mathrm{o}}$ (England, 1974, 1975, 1976, 1977). For example, Goodrich Clay and Fairbanks Silt exhibit an increase of $z_{\mathrm{e}}$ with freezing (Table $1 \mathrm{~b}$ ).

The effective emission depth of moist soils is typically $10 \%$ of the free-space wavelength. Frozen soils have effective emission depths that may be $30 \%$ or more of free-space wavelength. The effective emission depth of frozen sandy soils, like the Fairbanks Silt, can be several wavelengths. In the more transparent emitting media, particularly in frozen sandy soil or dry snow, the greater average thermal photon path lengths have two effects: a greater likelihood that thermal gradients affect spectral gradients, and a greater opportunity for volume scattering of photons.

Thermally induced spectral gradients occur because longer wavelength photons tend to originate below the optical surface where thermal temperatures may differ by several degrees from surface temperatures. For the lower loss tangents of frozen soil, this difference in average emitting depth is enough to reflect near surface thermal gradients caused by diurnal heating. That is, a positive thermal gradient, $\partial T_{\mathrm{o}} / \partial z$, where $z$ is depth in the soil, will yield a negative spectral gradient, $\partial T_{\mathrm{b}} / \partial f$, where $f$ is microwave frequency. SMMR data are collected at midnight and noon. In the absence of changing weather conditions, midnight thermal gradients will be positive and noon thermal gradients will be negative. This negative shift in the thermal gradient between midnight and noon will cause a positive shift in the spectral gradient. The SMMR radiometric brightness exhibits an average $+0.2 \mathrm{~K}$ per $f(\mathrm{GHz})$ shift between midnight and noon (Fig. 2). We are developing a computer model of these gradient effects. For now, thermally induced spectral gradients are noise to be filtered out.

The second consequence of soil freezing is a greater opportunity for volume scattering, particularly at shorter microwave wavelengths. This occurs be- 

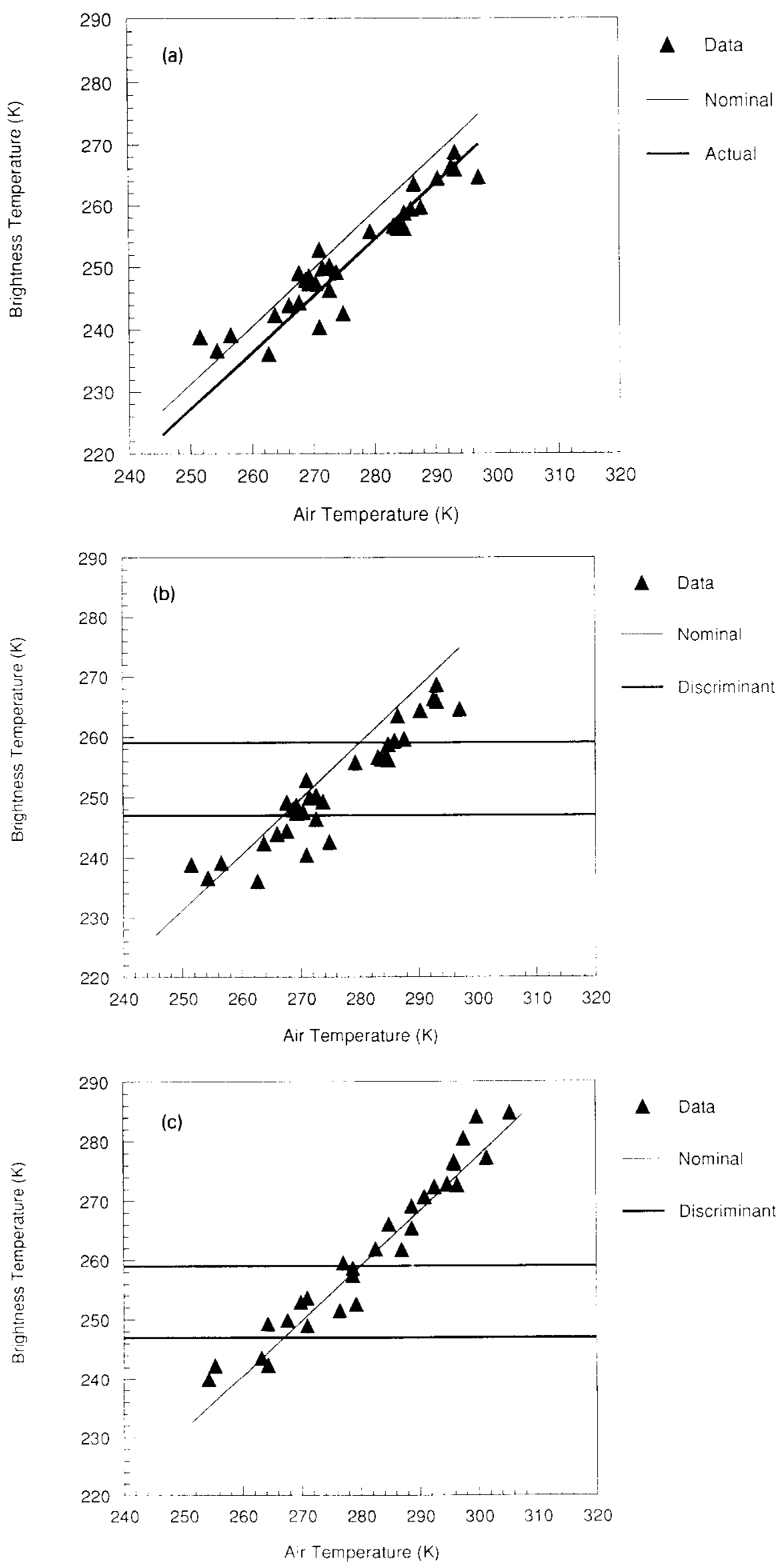

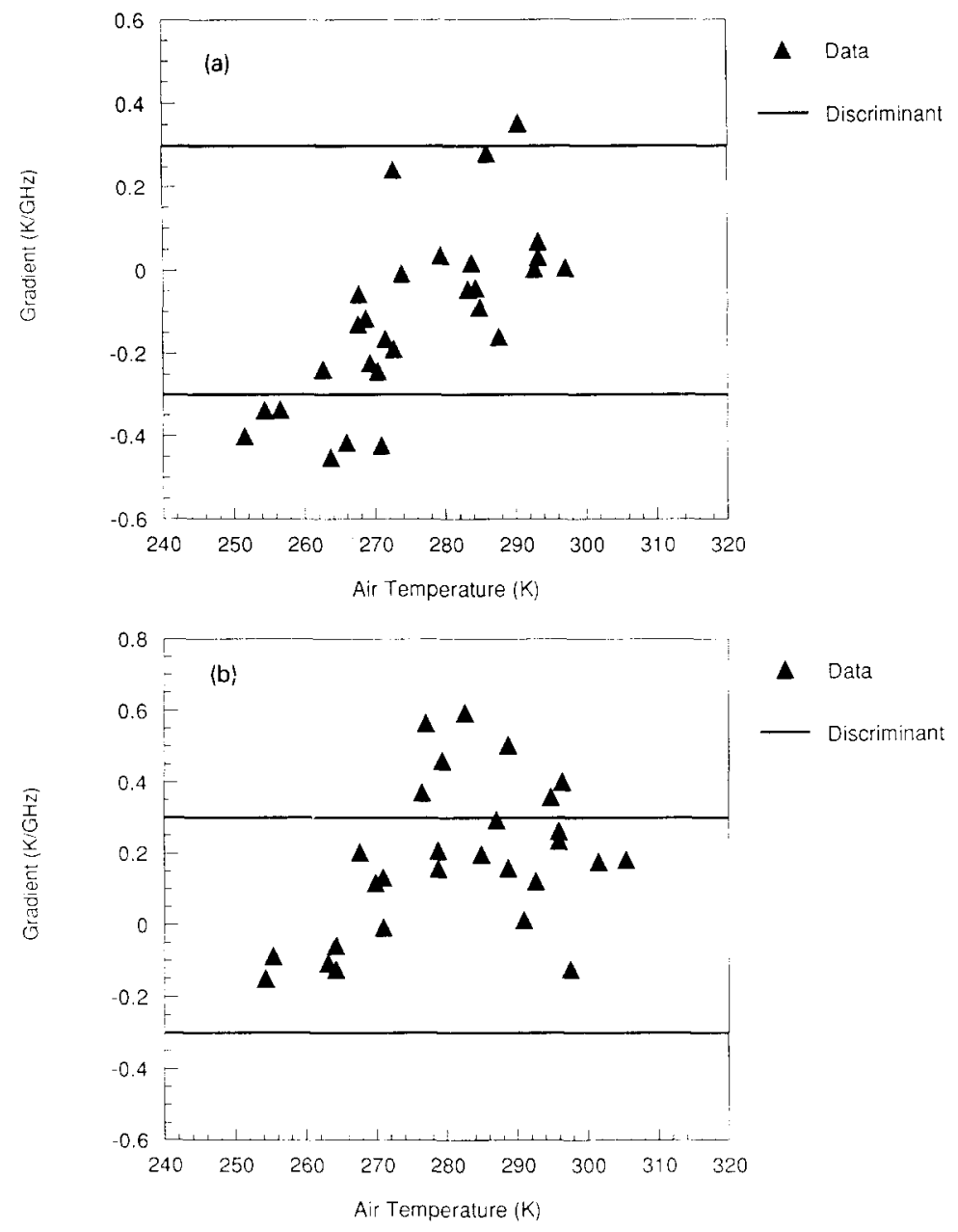

Fig. 2. Frequency gradient vs. measured surface air temperature, Bismark, North Dakota. Data were collected from 1 August to 31 December 1984. The frequency gradient is the frequency regression slope for simultaneous SMMR brightness temperatures at $37 \mathrm{GHz}, 18 \mathrm{GHz}$ and 10.7 $\mathrm{GHz}$. Shown with the Bismark data are frequency gradient decision thresholds for a frozen or thawed surface. (a) Midnight data. (b) Noon data.

Fig. 1. $37 \mathrm{GHz}$ SMMR brightness temperature vs. measured surface air temperature, Bismark, North Dakota. Data were collected from 1 August to 31 December 1984. (a) A linear regression of the Bismark data is shown ('actual' curve), with a regression line for data collected throughout North Dakota and the surrounding region ('nominal' curve). Data collected at midnight. (b) Shown with the Bismark data is a linear regression for data collected throughout North Dakota and the surrounding region ("nominal' curve). Also shown are brightness temperature decision thresholds for a frozen or thawed surface. Data collected at midnight. (c) Shown with the Bismark data is a linear regression for data collected throughout North Dakota and the surrounding region ('nominal' curve). Also shown are brightness temperature decision thresholds for a frozen or thawed surface. Data collected at noon. 
cause of the greater average photon path lengths in frozen soil, and because plants and soil appear increasingly heterogeneous at shorter wavelengths. This 'law of darkening' means that, for an isothermal, volume scattering halfspace (England, 1974),

$\frac{\partial T_{\mathrm{b}}}{\partial f}<0$

Edgerton et al. ( 1971) observed a negative spectral gradient for microwave emission from dry snow. Snow is exceedingly transparent to microwaves so that, like frozen soil, snow exhibits significant scatter-induced darkening (e.g. England, 1974). Consequently, a thick (several 10s of centimeters) snowpack might be misclassified as frozen soil. Such snow conditions do occur in the northern Great Plains, but they occur relatively infrequently. For example, the snow pack depth recorded at Bismarck, North Dakota (in the center of our test region ), was greater than $15 \mathrm{~cm}$ for only one day during the fall of 1984 (our test period).

While neither a low $37 \mathrm{GHz}$ radiobrightness nor a negative spectral gradient is solely adequate as a classifier of frozen soils, particularly at the relatively coarse resolutions of the Nimbus 7 SMMR, a discriminant based upon a combination of these signatures offers considerable promise. Our objective has been to determine whether such a discriminant is feasible.

RADIOBRIGHTNESS AND GROUND TEMPERATURES, AND THE CLASSIFICATION DISCRIMINANT

Nimbus 7 SMMR (Scanning Multichannel Microwave Radiometer) radiobrightness data at $6.6,10.7,18$ and $37 \mathrm{GHz}$ were obtained for 1 August 1984, through 31 December 1984, over an area that included North Dakota, about half of each neighboring state, and part of southern Canada (Figs. 57 ). We chose this large, relatively uniform area because of the low spatial resolution of the SMMR instruments, $150 \mathrm{~km}$ at $6.6 \mathrm{GHz}, 100 \mathrm{~km}$ at 10.7 $\mathrm{GHz}, 60 \mathrm{~km}$ at $18 \mathrm{GHz}$, and $30 \mathrm{~km}$ at $37 \mathrm{GHz}$, and because of the importance of soil moisture state to this region's hydrologic processes. The data arrived from the National Space Science Data Center (NSSDC) on 21, high density, SMMR Cell Tapes. Such data are referenced to latitude and longitude in a satellite-centered coordinate system. We produced two types of image products: (1) single-band, radiobrightness images at the intrinsic resolution of each sensor, and (2) composite, multi-band images at a common resolution. Each radiobrightness pixel was referenced to latitude-longitude in a Mercator projection by interpolation and resampling the Cell Tape data. We used a bi-cubic approximation of a sinc function (Moik, 1980) for the interpolation. $\mathrm{H}$ and $\mathrm{V}$ radiobrightnesses were averaged to produce a single brightness for each pixel for each frequency. 
In addition to large area images, local area spatial averages of radiobrightness were calculated for each radiobrightness channel at seven meteorologic sites within our test region: Miles City, MT; Bismark, Fargo and Williston, ND; and Abileen, Huron and Rapid City, SD. A local area is defined as a 150 $\mathrm{km}$ cell centered on a meteorological site $(150 \mathrm{~km}$ is the spatial resolution of the $6.6 \mathrm{GHz}$ channel ). Air and ground temperature data for the fall of 1984 were obtained from the NOAA National Climatic Data Center in Asheville, NC. Air temperature measurements were available for noon and midnight at the meteorologic sites (i.e. simultaneously with the satellite pass), but ground temperature measurements were for 7:00 a.m. and 7:00 p.m. EST, and were not co-located with the meteorologic sites. Ground temperatures are measured at $5 \mathrm{~cm}$ depths. Diurnal heating will weakly affect $5 \mathrm{~cm}$ temperatures so that there will be some differences for the times of the satellite pass.

Local area averages at the meteorologic sites were used to define the preliminary boundaries in our Freeze Indicator (FI) discriminant. For example, Fig. 1 illustrated the correlation between $37 \mathrm{GHz}$ radiobrightness and reported air temperature. The nominal line in these figures is a single best fit linear regression, in the least squares sense, to all local area averages. Linear fits to individual sites will differ slightly, as shown in Fig. 1a. We used the nominal line in our discriminant for simplicity, but a more sophisticated discriminant might use the actual least squares fit for the local area and for the time of day. Discriminant boundaries in Fig. 1b,c are determined from nominal regressions and are compromises between the midnight and noon air temperatures that would imply frozen soil (the lower boundary) and thawed soil (the upper boundary). Diurnal temperature gradients will generally cause midnight, sub-surface soil temperatures to be warmer than air temperatures, and noon, sub-surface soil temperatures to be colder.

Similarly, local area averages of spectral gradient vs. air temperature were the bases for the spectral gradient decision boundaries shown in Fig. 2. Note that the midnight freeze boundary in this example is relatively unambiguous, while a more effective noon freeze boundary would be shifted upwards by 0.2 $\mathrm{K} \mathrm{GHz}^{-1}$. Again, for simplicity in this preliminary study, we used discriminant boundaries that were time and location independent.

Our 2-parameter FI incorporates the single-band, $37 \mathrm{GHz}$ radiobrightness, and a spectral gradient based upon linear regression of $10.7,18$ and $37 \mathrm{GHz}$ radiobrightnesses for each pixel. Based upon the decision boundaries in Fig. $1 \mathrm{~b}, \mathrm{c}$, the likelihood of frozen ground in a $37 \mathrm{GHz}$ pixel, $p_{37}$, is estimated as

$$
p_{37}= \begin{cases}0 & T_{\mathrm{b}}(37)>T_{\mathrm{b}_{\max }} \\ \frac{T_{\mathrm{b}_{\max }}-T_{\mathrm{b}}(37)}{T_{\mathrm{b}_{\max }}-T_{\mathrm{b}_{\min }}} & T_{\mathrm{b}_{\min }}<T_{\mathrm{b}}(37)<T_{\mathrm{b}_{\max }} \\ 1 & T_{\mathrm{b}}(37)<T_{\mathrm{b}_{\min }}\end{cases}
$$


where $T_{\mathrm{b}}(37)$ is the measured $37 \mathrm{GHz}$ radiobrightness, and the preliminary decision boundaries are:

$T_{\mathrm{b}_{\max }}=259 \mathrm{~K}$
$T_{\mathrm{b}_{\min }}=247 \mathrm{~K}$
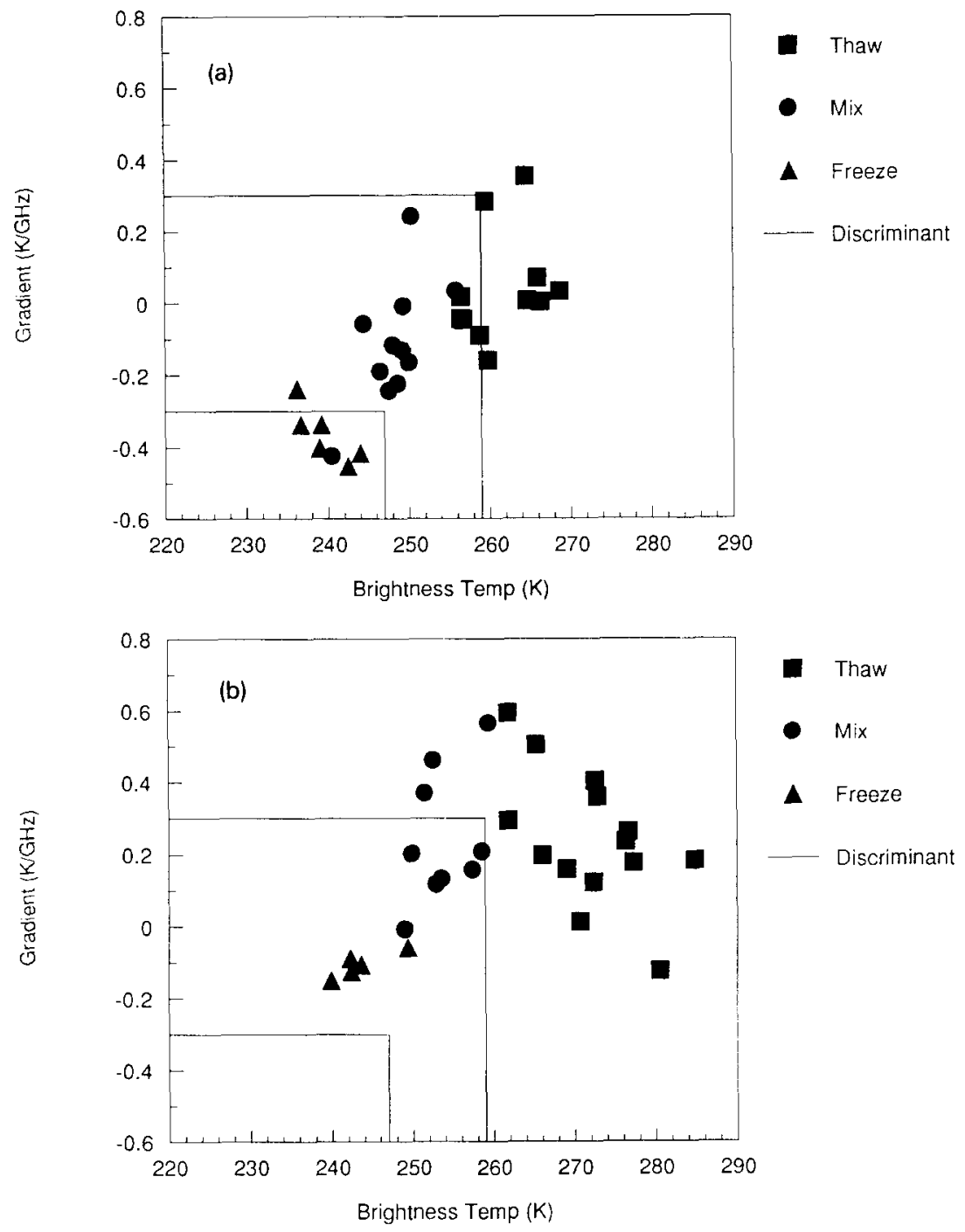

Fig. 3. Frequency gradient vs. SMMR $37 \mathrm{GHz}$ brightness temperature, Bismark, North Dakota. Data were collected from 1 August to 31 December 1984. Shown with the Bismark data are clustering decision thresholds for a frozen, mixed, or thawed surface. Based upon ground truth: triangles are frozen, squares are thawed, and circles are mixed pixels. (a) Midnight data. (b) Noon data. 
The likelihood of frozen ground based upon spectral gradient decision boundaries in Fig. 2a,b is $p_{\mathrm{sg}}$, and is estimated as

$$
p_{\mathrm{sg}}= \begin{cases}0 & \frac{\partial T_{\mathrm{b}}}{\partial f}>\left(\frac{\partial T_{\mathrm{b}}}{\partial f}\right)_{\text {max }} \\ \frac{\left(\frac{\partial T_{\mathrm{b}}}{\partial f}\right)_{\max }-\frac{\partial T_{\mathrm{b}}}{\partial f}}{\left(\frac{\partial T_{\mathrm{b}}}{\partial f}\right)_{\text {max }}-\left(\frac{\partial T_{\mathrm{b}}}{\partial f}\right)_{\min }} & \left(\frac{\partial T_{\mathrm{b}}}{\partial f}\right)_{\text {min }}<\frac{\partial T_{\mathrm{b}}}{\partial f}<\left(\frac{\partial T_{\mathrm{b}}}{\partial f}\right)_{\text {max }} \\ 1 & \frac{\partial T_{\mathrm{b}}}{\partial f}<\left(\frac{\partial T_{\mathrm{b}}}{\partial f}\right)_{\text {min }}\end{cases}
$$

where the preliminary decision boundaries are:

$\left(\frac{\partial T_{\mathrm{b}}}{\partial f}\right)_{\max }=0.3 \mathrm{~K} \mathrm{GHz}^{-1}$

$\left(\frac{\partial T_{\mathrm{b}}}{\partial f}\right)_{\min }=-0.3 \mathrm{~K} \mathrm{GHz}^{-1}$

These boundaries are preliminary in that they were chosen to yield the fewest misclassifications in plots of the type shown in Fig. 3a,b. More refined discriminants would incorporate area- and time-specific decision boundaries. This would be relatively straightforward if there were a higher density of weather stations in the test area. As it is, we believe that diurnal temperature modeling will yield effective time-dependent boundaries, and, perhaps, requiring sub-region consistency within a classification will yield improved spatially dependent boundaries. These refinements are to be part of our continuing project. However, it is the basic sparseness and lack of control of air and ground data that should prompt some caution about over-interpreting our results.

Our freeze/thaw discriminant, or FI, is the product of $p_{37}$ and $p_{\mathrm{sg}}$, and is applied at the scale of the $10.7 \mathrm{GHz}$ data. Resolution differences between different frequency channels can produce anomalous composite image results if the data were processed directly at their original scale. To avoid these problems, the resolution of the data from each channel is compensated to the (coarse) resolution of the lowest frequency channel used in estimating spectral gradients (i.e. $10.7 \mathrm{GHz}$ and $100 \mathrm{~km}$ resolution). Under certain constraints upon the classification process, these images can be referenced to the higher resolution, $37 \mathrm{GHz}$ format for better location of freeze/thaw boundaries (Zuerndorfer et al., 1989). The effort needed to do this would be justified as a part of an improved classification process. (Figures 5-10 include images of the FI for various times during the test period.) In these images black indicates a high likelihood of frozen ground, very light grey indicates a low likelihood of frozen ground, and pure white indicates no satellite data was available. 


\section{OBSERVATIONS}

Figure $4 \mathrm{a}, \mathrm{b}$ shows normalized brightness temperatures for midnight and noon, respectively, in the northern Great Plains during the fall of 1984. Normalized brightnesses are the average regional brightness at each microwave frequency divided by the average regional air temperature. Normalized
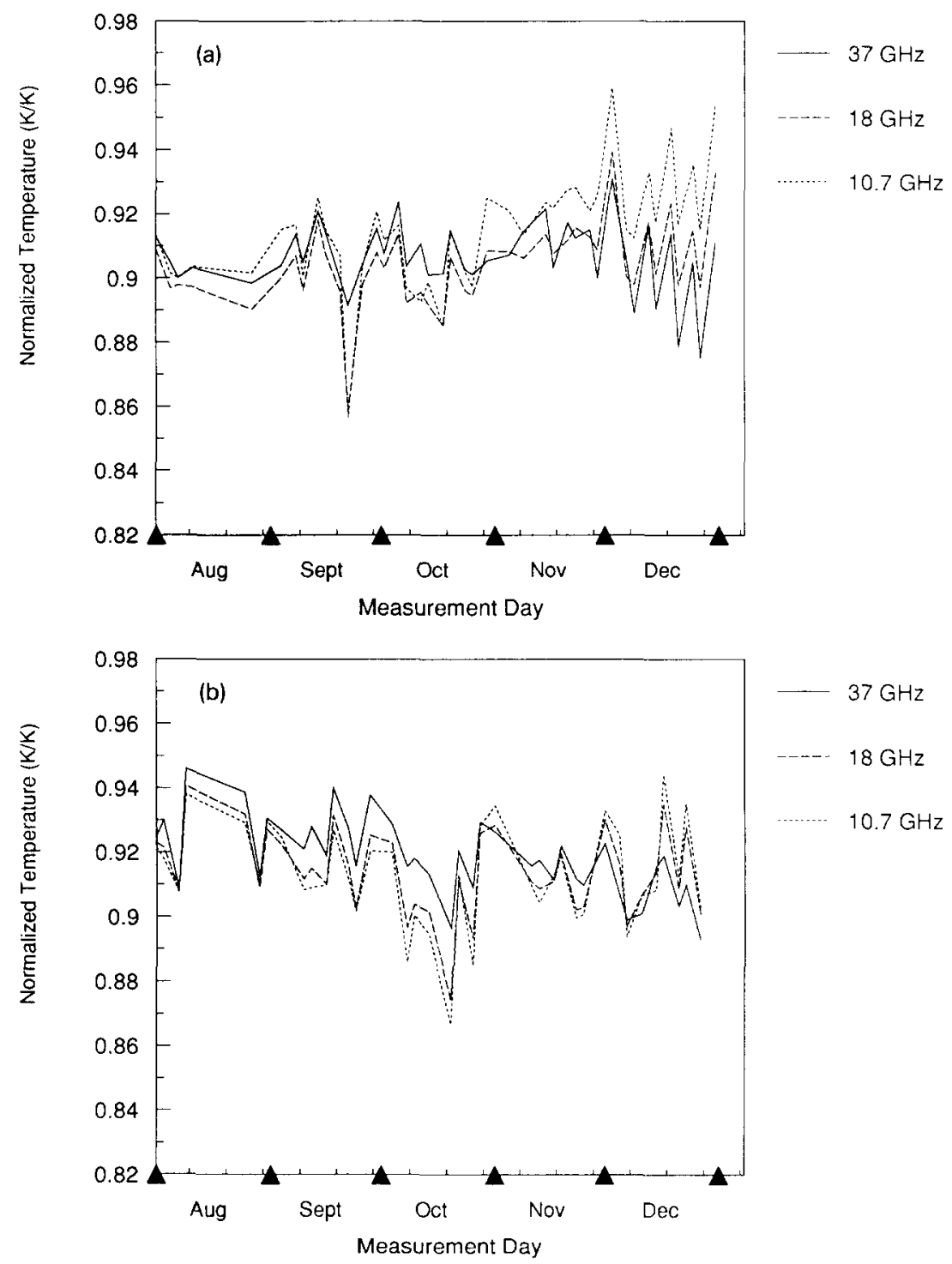

$37 \mathrm{GHz}$

$18 \mathrm{GHz}$

$10.7 \mathrm{GHz}$

Fig. 4. $37 \mathrm{GHz}, 18 \mathrm{GHz}$ and $10.7 \mathrm{GHz}$ SMMR normalized brightness temperatures vs. calendar day. Measurements were made at irregular intervals from 1 August to 31 December 1984 (day and night measurements were generally not made within $24 \mathrm{~h}$ ). The normalized brightness temperature of a single SMMR frequency channel is the average brightness divided by the average surface air temperature, averages are calculated over North Dakota and the surrounding region.

(a) Midnight data. (b) Noon data. 

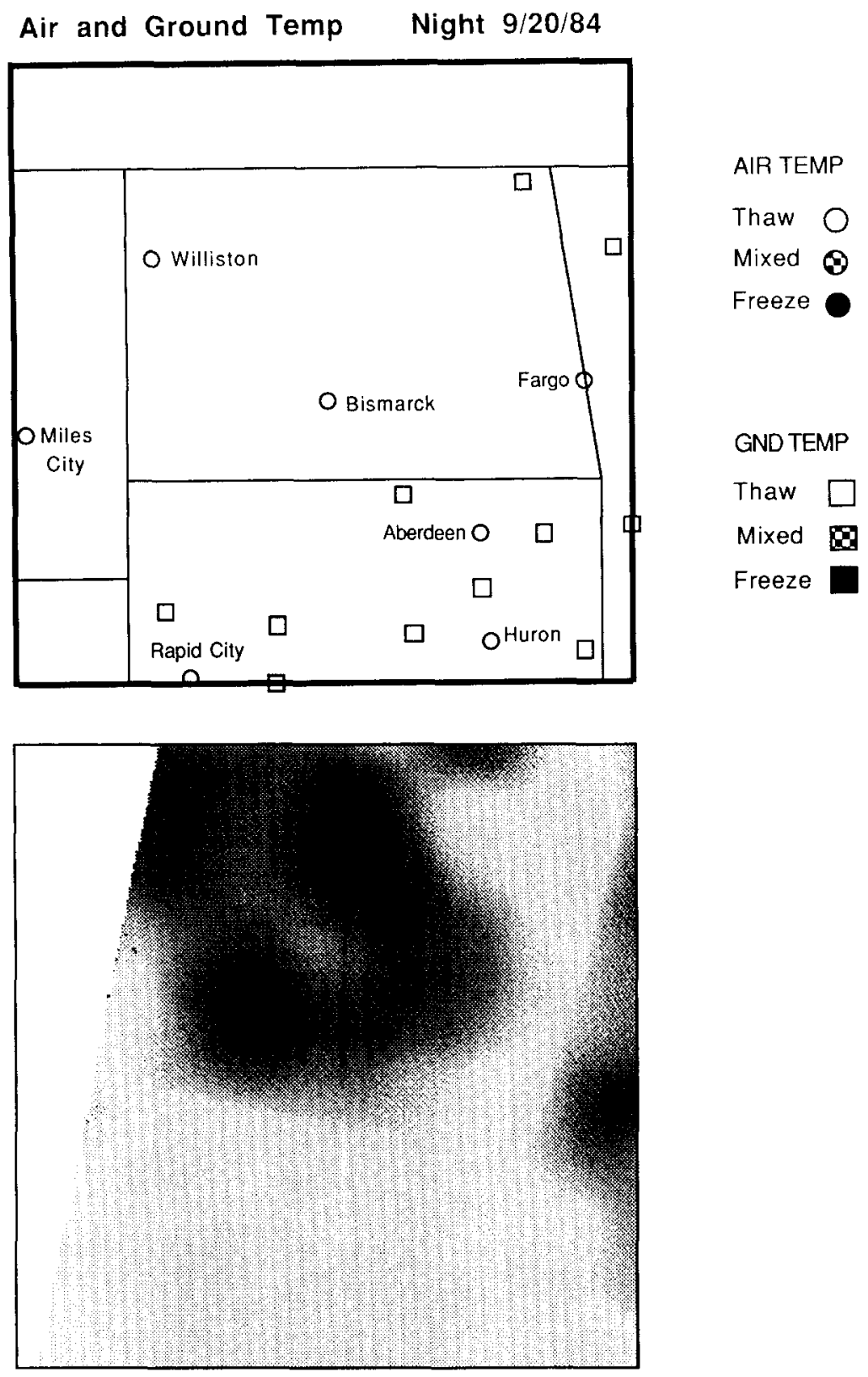

Fig. 5. A comparison of reported air and ground temperatures with the FI for midnight, 20 September 1984.

brightness thus has the dimension of emissivity. Note that there is little systematic ordering among the $10.7,18$ and $37 \mathrm{GHz}$ normalized brightnesses during August through most of November. However, during the latter half of 

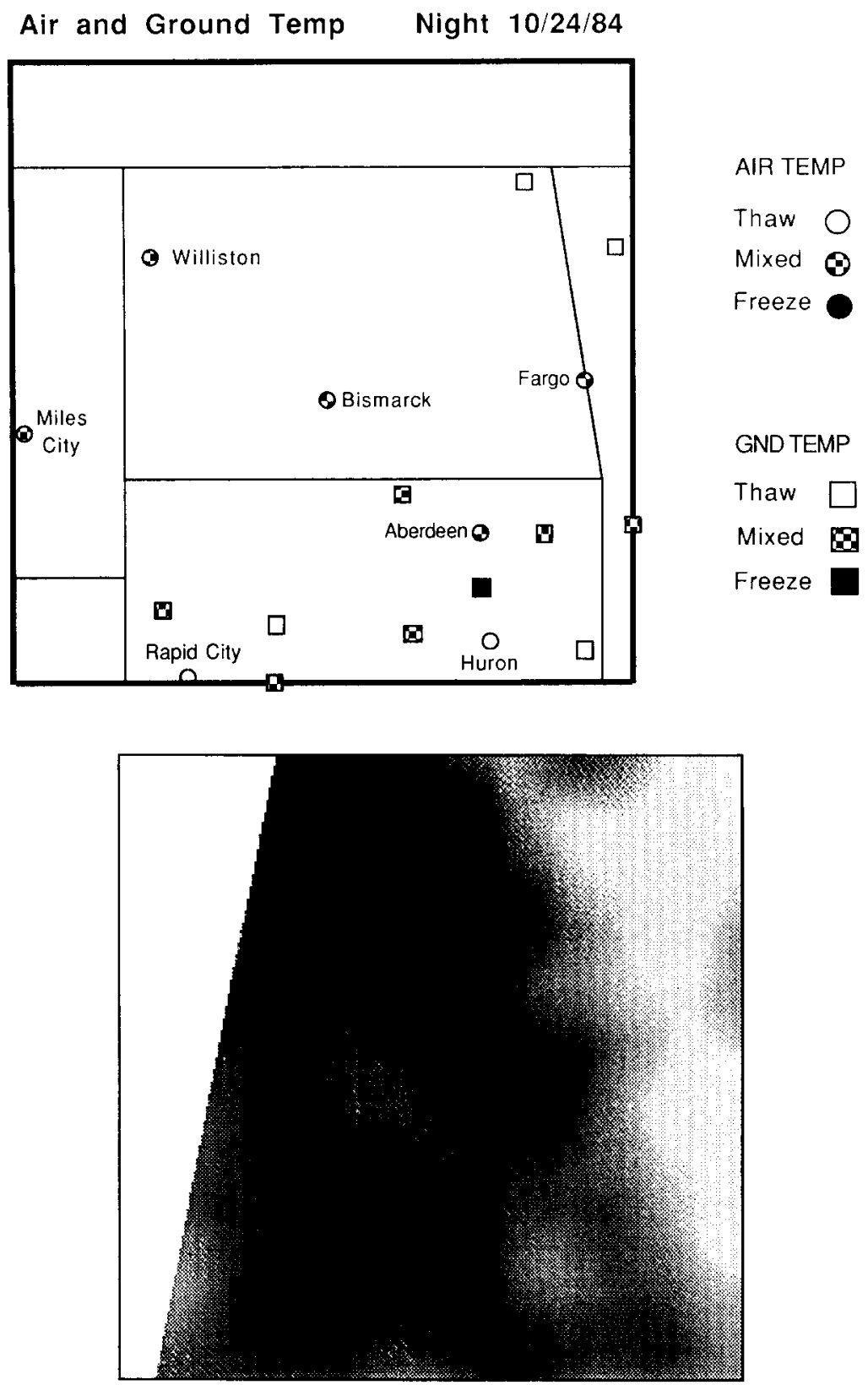

Fig. 6. A comparison of reported air and ground temperatures with the FI for midnight, 24 October 1984.

November through December, the normalized brightnesses at midnight are uniformly ordered, $10.7 \mathrm{GHz}$ brightnesses are high, $18 \mathrm{GHz}$ brightnesses are middle, and $37 \mathrm{GHz}$ brightnesses are low. That is, they exhibit negative av- 
Air and Ground Temp Night 12/9/84
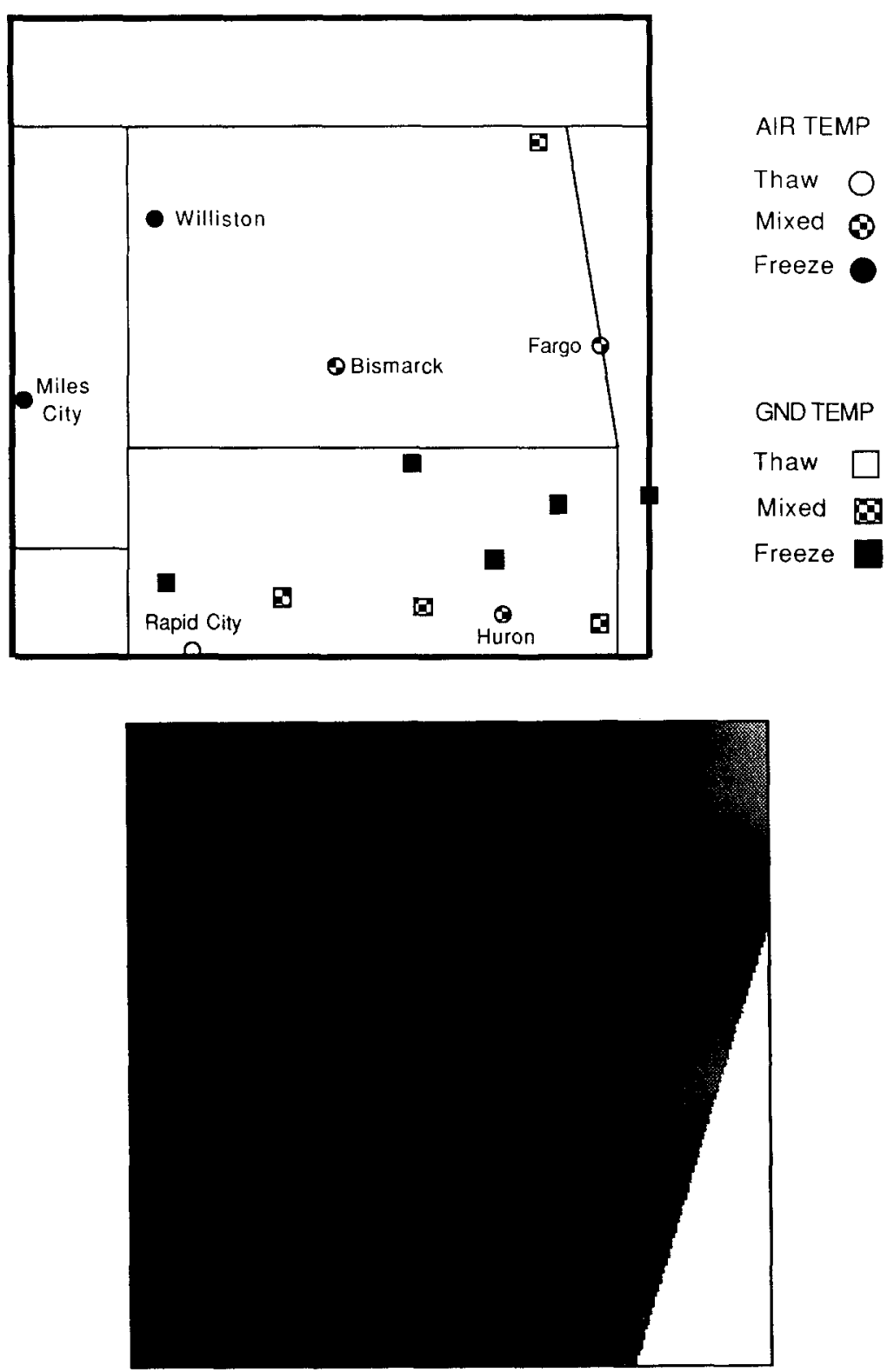

Fig. 7. A comparison of reported air and ground temperatures with the FI for midnight, 9 December 1984.

erage spectral gradients. The noon-normalized brightnesses for December exhibit a similar trend, but with exceptions. These are, we believe, illustrations of the law of darkening for frozen soils. Soils at midnight in December for the 
TABLE 2

Weather summary for 15-22 September $1984^{\mathrm{a}}$

\begin{tabular}{|c|c|c|c|c|c|c|c|c|c|c|}
\hline \multirow{2}{*}{$\begin{array}{l}\text { Date } \\
\text { September } \\
1984\end{array}$} & \multirow[t]{2}{*}{ Site } & \multicolumn{2}{|c|}{$\begin{array}{l}\text { Air temperature } \\
\left({ }^{\circ} \mathrm{F}\right)\end{array}$} & \multicolumn{2}{|c|}{$\begin{array}{l}\text { Cloud cover } \\
(\times / 10)\end{array}$} & \multicolumn{4}{|c|}{$\begin{array}{l}\text { Precipitation } \\
\text { (in.) }\end{array}$} & \multirow{2}{*}{$\begin{array}{l}\text { Snow pack } \\
\text { (in.) } \\
24 \mathrm{~h}\end{array}$} \\
\hline & & $00: 00$ & $12: 00$ & $00: 00$ & $12: 00$ & $00: 00$ & $12: 00$ & $24 \mathrm{~h}$ & Remarks & \\
\hline \multirow[t]{7}{*}{15} & Aberdeen & 40 & 63 & 2 & 3 & 0 & 0 & 0 & & 0 \\
\hline & Bismark & 39 & 64 & 0 & 0 & 0 & 0 & 0 & & 0 \\
\hline & Fargo & 46 & 63 & 8 & 0 & 0 & 0 & $\mathrm{~T}$ & & 0 \\
\hline & Huron & 44 & 64 & 0 & 3 & 0 & 0 & 0 & & 0 \\
\hline & Miles City & 50 & 65 & 2 & 2 & 0 & 0 & 0 & & 0 \\
\hline & Rapid City & 44 & 63 & 4 & 2 & 0 & 0 & 0 & & 0 \\
\hline & Williston & 48 & 60 & 6 & 0 & 0 & 0 & 0 & & 0 \\
\hline \multirow[t]{7}{*}{16} & Aberdeen & 46 & 65 & 1 & 3 & 0 & 0 & 0 & & 0 \\
\hline & Bismark & 53 & 67 & 0 & 2 & 0 & 0 & 0 & & 0 \\
\hline & Fargo & 47 & 69 & 0 & 0 & 0 & 0 & 0 & & 0 \\
\hline & Huron & 50 & 64 & 5 & 10 & 0 & 0 & 0 & & 0 \\
\hline & Miles City & 58 & 74 & 0 & 3 & - & - & 0 & & 0 \\
\hline & Rapid City & 52 & 70 & 3 & 6 & 0 & 0 & 0 & & 0 \\
\hline & Williston & 55 & 68 & 0 & 3 & 0 & 0 & 0 & & 0 \\
\hline \multirow[t]{7}{*}{17} & Aberdeen & 57 & 71 & 2 & 8 & 0 & 0 & 0 & & 0 \\
\hline & Bismark & 56 & 83 & 0 & 1 & 0 & 0 & 0 & & 0 \\
\hline & Fargo & 57 & 73 & 0 & 3 & 0 & 0 & 0 & & 0 \\
\hline & Huron & 58 & 73 & 10 & 3 & 0 & 0 & 0 & & 0 \\
\hline & Miles City & 61 & 80 & 0 & 0 & - & - & 0 & & 0 \\
\hline & Rapid City & 64 & 84 & 0 & 0 & 0 & 0 & 0 & & 0 \\
\hline & Williston & 56 & 74 & 0 & 3 & 0 & 0 & 0 & & 0 \\
\hline \multirow[t]{7}{*}{18} & Aberdeen & 64 & 81 & 0 & 0 & 0 & 0 & 0 & & 0 \\
\hline & Bismark & 57 & 80 & 0 & 0 & 0 & 0 & 0 & & 0 \\
\hline & Fargo & 64 & 81 & 0 & 0 & 0 & 0 & 0 & & 0 \\
\hline & Huron & 62 & 84 & 0 & 0 & 0 & 0 & 0 & & 0 \\
\hline & Miles City & 60 & 80 & 0 & 0 & - & - & 0 & & 0 \\
\hline & Rapid City & 63 & 90 & 0 & 0 & 0 & 0 & 0 & & 0 \\
\hline & Williston & 67 & 73 & 0 & 0 & 0 & 0 & 0 & & 0 \\
\hline \multirow[t]{7}{*}{19} & Aberdeen & 59 & 84 & 0 & 1 & 0 & 0 & 0 & & 0 \\
\hline & Bismark & 55 & 86 & 0 & 0 & 0 & 0 & 0 & & 0 \\
\hline & Fargo & 65 & 90 & 0 & 0 & 0 & 0 & 0 & & 0 \\
\hline & Huron & 68 & 90 & 0 & 0 & 0 & 0 & 0 & & 0 \\
\hline & Miles City & 67 & 76 & 0 & 0 & - & - & 0 & & 0 \\
\hline & Rapid City & 60 & 90 & 0 & 0 & 0 & 0 & 0 & & 0 \\
\hline & Williston & 57 & 72 & 0 & 0 & 0 & 0 & 0 & & 0 \\
\hline
\end{tabular}


TABLE 2 (continued)

\begin{tabular}{|c|c|c|c|c|c|c|c|c|c|c|}
\hline \multirow{2}{*}{$\begin{array}{l}\text { Date } \\
\text { September } \\
1984\end{array}$} & \multirow[t]{2}{*}{ Site } & \multicolumn{2}{|c|}{$\begin{array}{l}\text { Air temperature } \\
\left({ }^{\circ} \mathrm{F}\right)\end{array}$} & \multicolumn{2}{|c|}{$\begin{array}{l}\text { Cloud cover } \\
(x / 10)\end{array}$} & \multicolumn{4}{|c|}{$\begin{array}{l}\text { Precipitation } \\
\text { (in.) }\end{array}$} & \multirow{2}{*}{$\begin{array}{l}\text { Snow pack } \\
\text { (in.) } \\
24 \mathrm{~h}\end{array}$} \\
\hline & & $00: 00$ & $12: 00$ & 00:00 & $12: 00$ & $00: 00$ & $12: 00$ & $24 \mathrm{~h}$ & Remarks & \\
\hline \multirow[t]{7}{*}{20} & Aberdeen & 62 & 65 & 0 & 9 & 0 & 0 & 0 & & 0 \\
\hline & Bismark & 58 & 63 & 0 & 9 & 0 & 0 & 0 & & 0 \\
\hline & Fargo & 54 & 62 & 0 & 6 & 0 & 0 & 0 & & 0 \\
\hline & Huron & 62 & 71 & 0 & 2 & 0 & 0 & 0 & & 0 \\
\hline & Miles City & 63 & 72 & 7 & 2 & - & - & $\mathrm{T}$ & & 0 \\
\hline & Rapid City & 59 & 67 & 2 & 6 & 0 & 0 & 0 & & 0 \\
\hline & Williston & 54 & 51 & 8 & 9 & 0 & 0.01 & 0.15 & (R) & 0 \\
\hline \multirow[t]{7}{*}{21} & Aberdeen & 59 & 82 & 2 & 2 & 0 & 0 & 0.1 & & 0 \\
\hline & Bismark & 58 & 81 & 8 & 7 & 0 & 0 & 0.3 & (R) & 0 \\
\hline & Fargo & 59 & 77 & 10 & 9 & 0 & 0 & 0 & & 0 \\
\hline & Huron & 60 & 83 & 0 & 0 & 0 & 0 & 0 & & 0 \\
\hline & Miles City & 66 & 56 & 10 & 10 & - & - & 0.18 & (R) & 0 \\
\hline & Rapid City & 60 & 83 & 2 & 1 & 0 & 0 & 0.07 & (R) & 0 \\
\hline & Williston & 57 & 54 & 10 & 10 & 0.02 & 0.01 & 0.3 & (R) & 0 \\
\hline \multirow[t]{7}{*}{22} & Aberdeen & 61 & 65 & 8 & 2 & $\mathrm{~T}$ & 0 & $\mathrm{~T}$ & & 0 \\
\hline & Bismark & 52 & 60 & 3 & 1 & 0 & 0 & 0 & & 0 \\
\hline & Fargo & 72 & 66 & 9 & 0 & $T$ & 0 & 0.02 & & 0 \\
\hline & Huron & 66 & 66 & 10 & 2 & 0.05 & 0 & 0.011 & $(\mathrm{R})$ & 0 \\
\hline & Miles City & 46 & 52 & 4 & 6 & - & - & 0 & & 0 \\
\hline & Rapid City & 45 & 60 & 3 & 4 & 0 & 0 & 0 & & 0 \\
\hline & Williston & 45 & 44 & 10 & 9 & 0 & 0 & 0 & & 0 \\
\hline
\end{tabular}

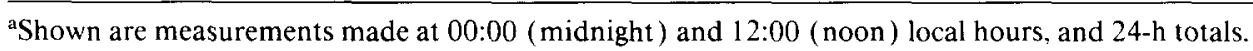
Trace, rain and snow conditions are indicated $T, R$ and $S$, respectively.

northern Great Plains are very likely to be frozen. The noon data are mixed because of daytime surface thawing (December was anomalously warm, Table 4).

Performance of the freeze/thaw discriminant is demonstrated in Figs. 5-7 where FI images are compared with ground and air temperature measurements for midnight on 20 September, 24 October and 9 December 1984. Midnight FI images are shown as better examples of the potential of a freeze discriminant. Noon FI images are generally less consistent with meteorologic reports, because of the contribution of the noontime positive diurnal spectral gradient to the negative frozen ground spectral gradient that we discussed in the last section. Areas not covered by the satellite in a particular pass are shown in white. Tables 2-4 are summaries of the meteorologic reports.

On the night of 20 September (Fig. 5), air temperatures throughout the region were near $60^{\circ} \mathrm{F}$ and had been above freezing for several days. The FI 
TABLE 3

Weather summary for 19-26 October $1984^{a}$

\begin{tabular}{|c|c|c|c|c|c|c|c|c|c|c|}
\hline \multirow{2}{*}{$\begin{array}{l}\text { Date } \\
\text { October } \\
1984\end{array}$} & \multirow[t]{2}{*}{ Site } & \multicolumn{2}{|c|}{$\begin{array}{l}\text { Air temperature } \\
\left({ }^{\circ} \mathrm{F}\right)\end{array}$} & \multicolumn{2}{|c|}{$\begin{array}{l}\text { Cloud cover } \\
(x / 10)\end{array}$} & \multicolumn{4}{|c|}{$\begin{array}{l}\text { Precipitation } \\
\text { (in.) }\end{array}$} & \multirow{2}{*}{$\begin{array}{l}\text { Snow pack } \\
\text { (in.) } \\
24 \mathrm{~h}\end{array}$} \\
\hline & & 00:00 & $12: 00$ & 00:00 & $12: 00$ & $00: 00$ & $12: 00$ & $24 \mathrm{~h}$ & Remarks & \\
\hline \multirow[t]{7}{*}{19} & Aberdeen & 37 & 44 & 10 & 8 & 0.01 & 0 & 0.1 & $(\mathrm{R})$ & 0 \\
\hline & Bismark & 36 & 40 & 10 & 10 & 0 & 0 & 0.04 & (S) & 0 \\
\hline & Fargo & 40 & 38 & 10 & 10 & 0.07 & 0.2 & 0.77 & (R) & 0 \\
\hline & Huron & 38 & 45 & 10 & 7 & 0.1 & 0 & 0.01 & & 0 \\
\hline & Miles City & 28 & 39 & 7 & 4 & - & - & $\mathrm{T}$ & & 0 \\
\hline & Rapid City & 26 & 42 & 2 & 7 & 0 & $\mathrm{~T}$ & $\mathrm{~T}$ & & $\mathrm{~T}$ \\
\hline & Williston & 27 & 34 & 2 & 10 & - & - & 0.1 & (S) & 0 \\
\hline \multirow[t]{7}{*}{20} & Aberdeen & 36 & 44 & - & 10 & 0 & 0 & $\mathrm{~T}$ & & 0 \\
\hline & Bismark & 35 & 38 & 9 & 10 & $\mathrm{~T}$ & 0.01 & 0.1 & (R) & 0 \\
\hline & Fargo & 37 & 42 & 10 & 10 & $T$ & 0.01 & 0.12 & (R) & 0 \\
\hline & Huron & 35 & 41 & 0 & 10 & 0 & 0 & $\mathrm{~T}$ & & 0 \\
\hline & Miles City & 31 & 33 & 10 & 10 & - & - & 0.01 & (S) & 0 \\
\hline & Rapid City & 26 & 43 & 0 & 0 & 0 & 0 & $\mathrm{~T}$ & (S) & 0 \\
\hline & Williston & 33 & 33 & 10 & 10 & 0.02 & 0 & 0.08 & (S) & $T$ \\
\hline \multirow[t]{7}{*}{21} & Aberdeen & 37 & 41 & - & 10 & 0 & 0 & $\mathrm{~T}$ & & 0 \\
\hline & Bismark & 36 & 37 & 10 & 10 & 0 & 0 & 0.03 & (S) & 0 \\
\hline & Fargo & 38 & 39 & 10 & 9 & 0 & $\mathrm{~T}$ & 0.07 & (R) & 0 \\
\hline & Huron & 35 & 44 & 2 & 6 & 0 & 0 & $\mathrm{~T}$ & & 0 \\
\hline & Miles City & 29 & 32 & 8 & 9 & - & - & $\mathrm{T}$ & & $\mathrm{T}$ \\
\hline & Rapid City & 33 & 38 & 10 & 10 & $\mathrm{~T}$ & 0 & $\mathrm{~T}$ & (S) & $\mathrm{T}$ \\
\hline & Williston & 32 & 33 & 10 & 9 & 0.01 & 0 & $\mathrm{~T}$ & (S) & $\mathrm{T}$ \\
\hline \multirow[t]{7}{*}{22} & Aberdeen & 34 & 41 & 7 & 8 & 0 & 0 & $\mathrm{~T}$ & & $\mathrm{~T}$ \\
\hline & Bismark & 33 & 39 & 10 & 8 & 0 & 0 & 0 & & $\mathrm{~T}$ \\
\hline & Fargo & 36 & 38 & 10 & 10 & $\mathrm{~T}$ & 0 & $\mathrm{~T}$ & & 0 \\
\hline & Huron & 31 & 42 & 0 & 3 & 0 & 0 & 0 & & 0 \\
\hline & Miles City & 25 & 38 & 0 & 7 & - & - & 0 & & 0 \\
\hline & Rapid City & 24 & 43 & 3 & 8 & 0 & 0 & 0 & & 0 \\
\hline & Williston & 27 & 32 & 7 & 10 & 0 & $\mathrm{~T}$ & $\mathrm{~T}$ & $(\mathrm{~S})$ & 0 \\
\hline \multirow[t]{7}{*}{23} & Aberdeen & 35 & 46 & 10 & 4 & 0 & 0 & 0 & & 0 \\
\hline & Bismark & 36 & 43 & 10 & 3 & 0 & 0 & 0 & & 0 \\
\hline & Fargo & 34 & 39 & 10 & 10 & 0 & 0 & 0 & & 0 \\
\hline & Huron & 32 & 46 & 3 & 5 & 0 & 0 & 0 & & 0 \\
\hline & Miles City & 23 & 37 & 1 & 0 & - & - & 0 & & 0 \\
\hline & Rapid City & 29 & 42 & 0 & 0 & 0 & 0 & 0 & & 0 \\
\hline & Williston & 27 & 40 & 10 & 0 & 0 & 0 & 0 & & 0 \\
\hline
\end{tabular}


TABLE 3 (continued)

\begin{tabular}{|c|c|c|c|c|c|c|c|c|c|c|}
\hline \multirow{2}{*}{$\begin{array}{l}\text { Date } \\
\text { October } \\
1984\end{array}$} & \multirow[t]{2}{*}{ Site } & \multicolumn{2}{|c|}{$\begin{array}{l}\text { Air temperature } \\
\left({ }^{\circ} \mathrm{F}\right)\end{array}$} & \multicolumn{2}{|c|}{$\begin{array}{l}\text { Cloud cover } \\
(x / 10)\end{array}$} & \multicolumn{4}{|c|}{$\begin{array}{l}\text { Precipitation } \\
\text { (in.) }\end{array}$} & \multirow{2}{*}{$\begin{array}{l}\text { Snow pack } \\
\text { (in.) } \\
24 \mathrm{~h}\end{array}$} \\
\hline & & 00:00 & $12: 00$ & $00: 00$ & $12: 00$ & $00: 00$ & $12: 00$ & $24 \mathrm{~h}$ & Remarks & \\
\hline \multirow[t]{7}{*}{24} & Aberdeen & 31 & 54 & 0 & 4 & 0 & 0 & 0 & & 0 \\
\hline & Bismark & 33 & 48 & 0 & 7 & 0 & 0 & 0 & & 0 \\
\hline & Fargo & 33 & 49 & 0 & 8 & 0 & 0 & 0 & & 0 \\
\hline & Huron & 36 & 57 & 0 & 1 & 0 & 0 & 0 & & 0 \\
\hline & Miles City & 35 & 44 & 5 & 10 & - & - & 0 & & 0 \\
\hline & Rapid City & 36 & 57 & 0 & 3 & 0 & 0 & 0 & & 0 \\
\hline & Williston & 30 & 42 & 5 & 7 & 0 & 0 & $\mathrm{~T}$ & & 0 \\
\hline \multirow[t]{7}{*}{25} & Aberdeen & 38 & 37 & 10 & 10 & 0 & 0 & 0 & & 0 \\
\hline & Bismark & 34 & 39 & 10 & 10 & 0 & 0 & 0 & & 0 \\
\hline & Fargo & 38 & 42 & 10 & 10 & 0 & 0 & 0 & & 0 \\
\hline & Huron & 43 & 40 & 8 & 10 & 0 & 0 & 0 & & 0 \\
\hline & Miles City & 33 & 44 & 10 & 10 & - & - & $\mathrm{T}$ & & 0 \\
\hline & Rapid City & 34 & 54 & 1 & 1 & 0 & 0 & 0 & & 0 \\
\hline & Williston & 30 & 42 & 10 & 10 & $\mathbf{T}$ & 0 & $\mathrm{~T}$ & & 0 \\
\hline \multirow[t]{7}{*}{26} & Aberdeen & 46 & 56 & 0 & 4 & 0 & 0 & 0 & & 0 \\
\hline & Bismark & 41 & 57 & 3 & 10 & 0 & 0 & 0 & & 0 \\
\hline & Fargo & 43 & 53 & 0 & 7 & 0 & 0 & 0 & & 0 \\
\hline & Huron & 46 & 61 & 0 & 0 & 0 & 0 & 0 & & 0 \\
\hline & Miles City & 44 & 52 & 0 & 10 & - & - & $\mathrm{T}$ & & 0 \\
\hline & Rapid City & 53 & 65 & 0 & 5 & 0 & 0 & 0 & & 0 \\
\hline & Williston & 39 & 50 & 6 & 10 & 0 & 0 & $\mathrm{~T}$ & $(\mathrm{R})$ & 0 \\
\hline
\end{tabular}

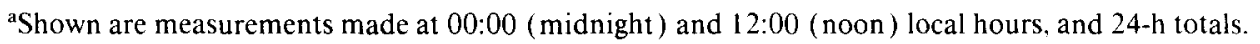
Trace, rain and snow conditions are indicated as $T, R$ and $S$, respectively.

image shows weak, probably false indications of freezing in the prairies of ND, southern Canada, and the rolling glacial terrain east of the Red River Valley in Minnesota. While the dry air of the northern prairies permits nighttime radiation cooling of the ground to temperatures below that of the air, the more likely explanation for the weak freeze indication is short wavelength scattering by the tall prairie grasses in the northern great plains, and by woodland areas in Minnesota. However, there are no strong indications of freezing in the FI image.

On the night of 24 October (Fig. 6), air temperatures hovered about freezing throughout the area, but had been below freezing at Williston for several days, and generally above freezing toward the east (see the temperatures for Fargo, Aberdeen and Huron in Table 2). The FI image shows a strong freeze indication in northwestern ND which is consistent with the temperature patterns. Similarly, the definite thaw indication along the Red River Valley is 
TABLE 4

Weather summary for 2-9 December $1984^{a}$

\begin{tabular}{|c|c|c|c|c|c|c|c|c|c|c|}
\hline \multirow{2}{*}{$\begin{array}{l}\text { Date } \\
\text { December } \\
1984\end{array}$} & \multirow[t]{2}{*}{ Site } & \multicolumn{2}{|c|}{$\begin{array}{l}\text { Air temperature } \\
\left({ }^{\circ} \mathrm{F}\right)\end{array}$} & \multicolumn{2}{|c|}{$\begin{array}{l}\text { Cloud cover } \\
(x / 10)\end{array}$} & \multicolumn{4}{|c|}{$\begin{array}{l}\text { Precipitation } \\
\text { (in.) }\end{array}$} & \multirow{2}{*}{$\begin{array}{l}\text { Snow pack } \\
\text { (in.) } \\
24 \mathrm{~h}\end{array}$} \\
\hline & & $00: 00$ & $12: 00$ & 00:00 & $12: 00$ & $00: 00$ & $12: 00$ & $24 \mathrm{~h}$ & Remarks & \\
\hline \multirow[t]{7}{*}{2} & Aberdeen & 17 & 10 & 10 & 4 & $\mathrm{~T}$ & 0 & $T$ & (S) & 2 \\
\hline & Bismark & 14 & 19 & 10 & 10 & $\mathrm{~T}$ & $\mathrm{~T}$ & 0.01 & $(\mathrm{~S})$ & 1 \\
\hline & Fargo & 8 & 3 & 10 & 10 & $\mathrm{~T}$ & $\mathrm{~T}$ & $\mathrm{~T}$ & (S) & $\mathrm{T}$ \\
\hline & Huron & 19 & 14 & 10 & 1 & 0.01 & $T$ & 0.07 & (S) & 6 \\
\hline & Miles City & 13 & 11 & 10 & 9 & - & - & 0.01 & (S) & 4 \\
\hline & Rapid City & 19 & 19 & 4 & 4 & 0 & 0 & $\mathrm{~T}$ & (S) & $\mathrm{T}$ \\
\hline & Williston & 11 & 8 & 10 & 8 & $T$ & 0 & $\mathrm{~T}$ & (S) & 1 \\
\hline \multirow[t]{7}{*}{3} & Aberdeen & 4 & 17 & 0 & 4 & 0 & 0 & $\mathrm{~T}$ & (S) & 2 \\
\hline & Bismark & 15 & 15 & 10 & 7 & $\mathrm{~T}$ & $\mathrm{~T}$ & $\mathrm{~T}$ & (S) & 1 \\
\hline & Fargo & 0 & 10 & 0 & 0 & 0 & $\mathrm{~T}$ & 0.1 & & $\mathrm{~T}$ \\
\hline & Huron & 5 & 14 & 0 & 0 & 0 & 0 & $\mathrm{~T}$ & (S) & 6 \\
\hline & Miles City & -3 & -2 & 10 & 1 & - & - & 0 & & 4 \\
\hline & Rapid City & 11 & 27 & 0 & 1 & 0 & 0 & 0 & & $T$ \\
\hline & Williston & 9 & 9 & 10 & 8 & $\mathrm{~T}$ & $\mathrm{~T}$ & $\mathrm{~T}$ & (S) & 1 \\
\hline \multirow[t]{7}{*}{4} & Aberdeen & 13 & 10 & 10 & 0 & 0 & 0 & 0.02 & (S) & 2 \\
\hline & Bismark & 8 & 15 & 10 & 1 & $\mathrm{~T}$ & 0 & $\mathrm{~T}$ & & 1 \\
\hline & Fargo & 9 & 15 & 10 & 0 & 0 & 0 & 0 & & $\mathrm{~T}$ \\
\hline & Huron & 5 & 12 & 6 & 2 & $\mathrm{~T}$ & 0 & $\mathrm{~T}$ & $(\mathrm{~S})$ & 5 \\
\hline & Miles City & -1 & 7 & 0 & 10 & - & - & 0 & & 4 \\
\hline & Rapid City & 15 & 24 & 2 & 0 & 0 & 0 & 0 & & $\mathrm{~T}$ \\
\hline & Williston & -5 & 10 & 0 & 10 & 0 & 0 & 0 & & 1 \\
\hline \multirow[t]{7}{*}{5} & Aberdeen & 14 & 7 & 3 & 5 & $\mathrm{~T}$ & 0 & $\mathrm{~T}$ & (S) & 2 \\
\hline & Bismark & 19 & -1 & 4 & 0 & 0 & 0 & $\mathrm{~T}$ & (S) & 1 \\
\hline & Fargo & 11 & -1 & 10 & 10 & 0 & 0 & $\mathrm{~T}$ & $(\mathrm{~S})$ & $T$ \\
\hline & Huron & 15 & 15 & 4 & 7 & 0 & $\mathrm{~T}$ & $\mathbf{T}$ & & 4 \\
\hline & Miles City & 24 & 13 & 10 & 10 & - & - & $\mathrm{T}$ & $(\mathrm{S})$ & 3 \\
\hline & Rapid City & 26 & 19 & 8 & 7 & 0 & $\mathrm{~T}$ & $\mathrm{~T}$ & (S) & $\mathrm{T}$ \\
\hline & Williston & 8 & -5 & 3 & 3 & $\mathrm{~T}$ & 0 & $T$ & (S) & 1 \\
\hline \multirow[t]{7}{*}{6} & Aberdeen & -14 & 3 & 0 & 0 & 0 & 0 & 0 & & 2 \\
\hline & Bismark & -11 & 20 & 0 & 8 & 0 & 0 & $T$ & & 1 \\
\hline & Fargo & -8 & 8 & 0 & 3 & 0 & 0 & 0 & & $\mathrm{~T}$ \\
\hline & Huron & -6 & 11 & 0 & 4 & 0 & 0 & 0 & & 4 \\
\hline & Miles City & 9 & 23 & 0 & 9 & - & - & 0 & & 3 \\
\hline & Rapid City & 6 & 44 & 1 & 1 & 0 & 0 & 0 & & $\mathrm{~T}$ \\
\hline & Williston & -7 & 24 & 0 & 9 & 0 & 0 & $\mathrm{~T}$ & & 1 \\
\hline
\end{tabular}

(continued) 
TABLE 4 (continued)

\begin{tabular}{|c|c|c|c|c|c|c|c|c|c|c|}
\hline \multirow{2}{*}{$\begin{array}{l}\text { Date } \\
\text { December } \\
1984\end{array}$} & \multirow[t]{2}{*}{ Site } & \multicolumn{2}{|c|}{$\begin{array}{l}\text { Air temperature } \\
\left({ }^{\circ} \mathrm{F}\right)\end{array}$} & \multicolumn{2}{|c|}{$\begin{array}{l}\text { Cloud cover } \\
(x / 10)\end{array}$} & \multicolumn{4}{|c|}{$\begin{array}{l}\text { Precipitation } \\
\text { (in.) }\end{array}$} & \multirow{2}{*}{$\begin{array}{l}\text { Snow pack } \\
\text { (in.) } \\
24 \mathrm{~h}\end{array}$} \\
\hline & & $00: 00$ & $12: 00$ & $00: 00$ & $12: 00$ & $00: 00$ & $12: 00$ & $24 \mathrm{~h}$ & Remarks & \\
\hline \multirow[t]{7}{*}{7} & Aberdeen & 18 & 42 & 7 & 4 & 0 & 0 & 0 & & 2 \\
\hline & Bismark & 30 & 43 & 9 & 8 & 0 & 0 & 0 & & 1 \\
\hline & Fargo & 12 & 43 & 7 & 9 & 0 & 0 & 0 & & $\mathrm{~T}$ \\
\hline & Huron & 19 & 42 & 3 & 0 & 0 & 0 & 0 & & 3 \\
\hline & Miles City & 35 & 44 & 4 & 0 & - & - & 0 & & 2 \\
\hline & Rapid City & 43 & 61 & 10 & 0 & 0 & 0 & 0 & & 0 \\
\hline & Williston & 34 & 43 & 3 & 6 & 0 & 0 & 0 & & 1 \\
\hline \multirow[t]{7}{*}{8} & Aberdeen & 30 & 36 & 2 & 3 & 0 & 0 & 0 & & $\mathrm{~T}$ \\
\hline & Bismark & 31 & 42 & 7 & 2 & 0 & 0 & 0 & & $\mathrm{~T}$ \\
\hline & Fargo & 30 & 43 & 2 & 5 & 0 & 0 & 0 & & 0 \\
\hline & Huron & 31 & 42 & 0 & 4 & 0 & 0 & 0 & & 1 \\
\hline & Miles City & 29 & 33 & 3 & 3 & - & - & 0 & & 1 \\
\hline & Rapid City & 33 & 51 & 0 & 10 & 0 & 0 & 0 & & 0 \\
\hline & Williston & 31 & 37 & 7 & 8 & 0 & 0 & 0 & & $\mathrm{~T}$ \\
\hline \multirow[t]{7}{*}{9} & Aberdeen & - & 46 & - & 7 & 0 & 0 & 0 & & $\mathrm{~T}$ \\
\hline & Bismark & 31 & 43 & 2 & 3 & 0 & 0 & 0 & & $\mathrm{~T}$ \\
\hline & Fargo & 29 & 40 & 0 & 9 & 0 & 0 & 0 & & 0 \\
\hline & Huron & 35 & 39 & 7 & 7 & 0 & 0 & 0 & & $\mathrm{~T}$ \\
\hline & Miles City & 26 & 35 & 5 & 4 & - & - & 0 & & 1 \\
\hline & Rapid City & 43 & 58 & 6 & 0 & 0 & 0 & 0 & & 0 \\
\hline & Williston & 28 & 37 & 0 & 2 & 0 & 0 & 0 & & 0 \\
\hline
\end{tabular}

aShown are measurements made at 00:00 (midnight) and 12:00 (noon) local hours, and 24-h totals. Trace, rain and snow conditions are indicated as $T, R$ and $S$, respectively.

consistent with the warmer temperatures reported and the generally more moist soil in the Valley.

On the night of 9 December (Fig. 7 ), air temperatures were generally below freezing except at Rapid City, SD, and had been below freezing for several days. There was no more than trace snow on the ground anywhere in the region. The FI image shows strong freeze indications throughout most of the region with weaker indications near Rapid City, and in the Aberdeen-Fargo sub-region (Aberdeen is not shown on the 9 December map because its temperature report was missing for that date). Again, the FI image is consistent with the temperature record.

The $37 \mathrm{GHz}$ radiobrightness and FI image sequences were produced at 
(a) 37 GHZ RADIOBRIGHTNESS

MIDNIGHT FREEZE INDICATOR
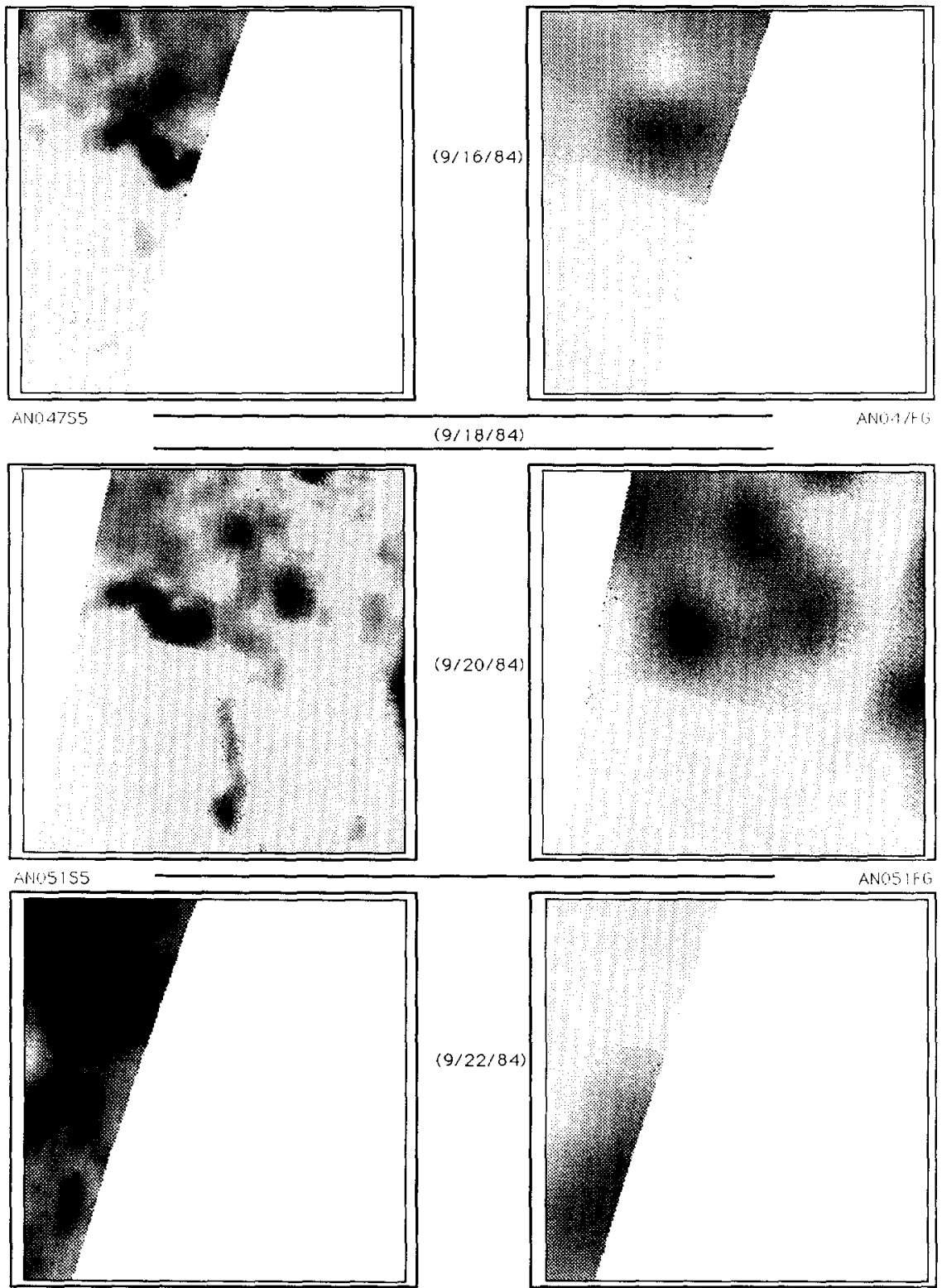

t.N05355

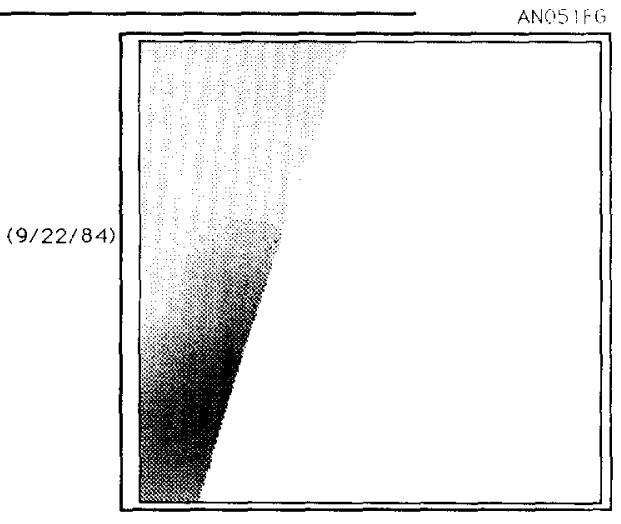

ANGS 5 -

Fig. 8. (a) $37 \mathrm{GHz}$ and FI image sequences for a 6-day period in September. Midnight data. (b) $37 \mathrm{GHz}$ and $\mathrm{Fl}$ image sequences for a 6-day period in September. Noon data. 
(b)

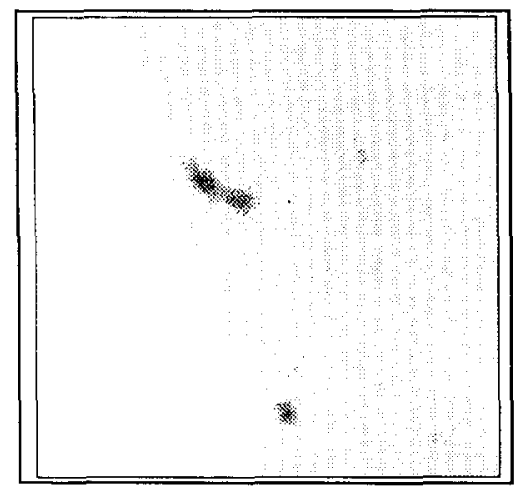

A.D0 4755

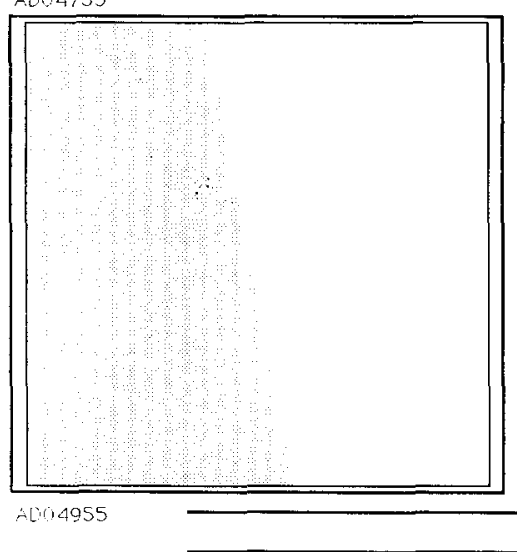

NOON

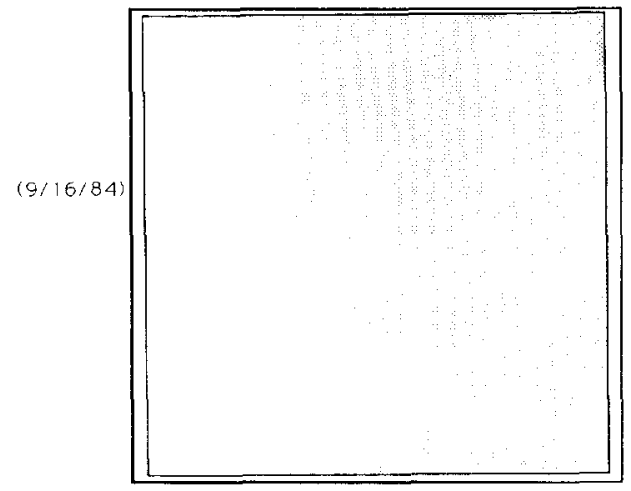

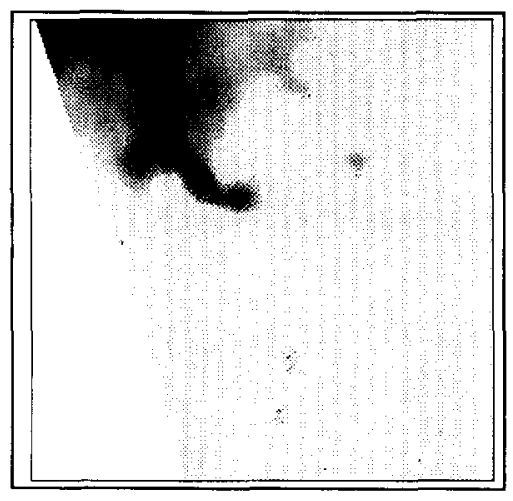

4005355

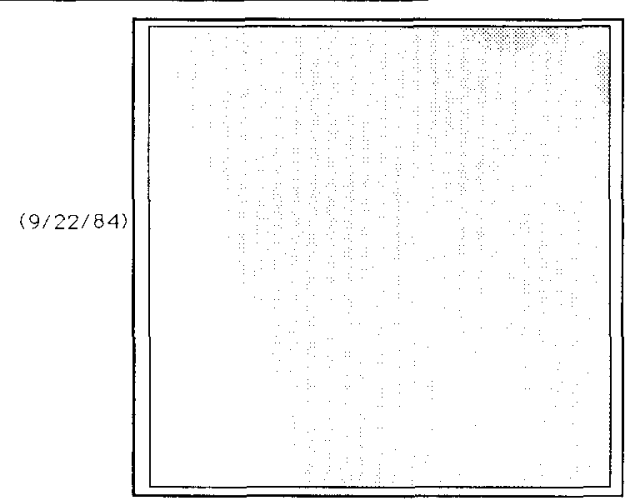

AD? 保:

Fig. 8 contd. 
(a)

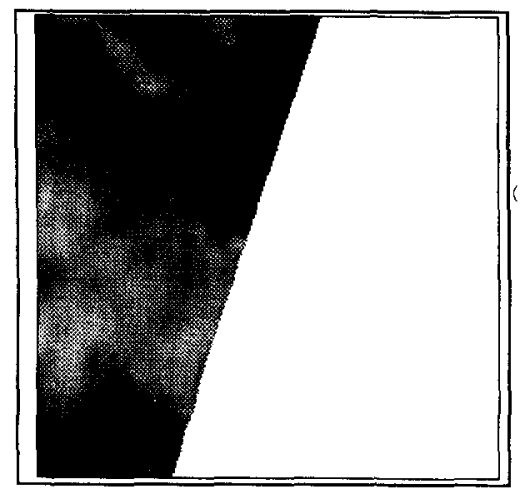

ANOB 155
MIDNIGHT

$0 / 20 / 84)$

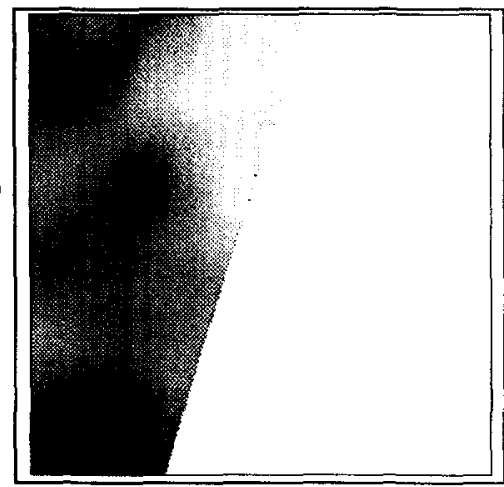

ANi: $: 1:$

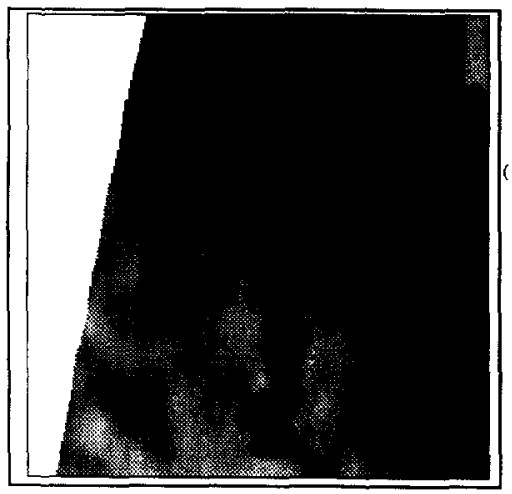

$(10 / 22 / 84)$

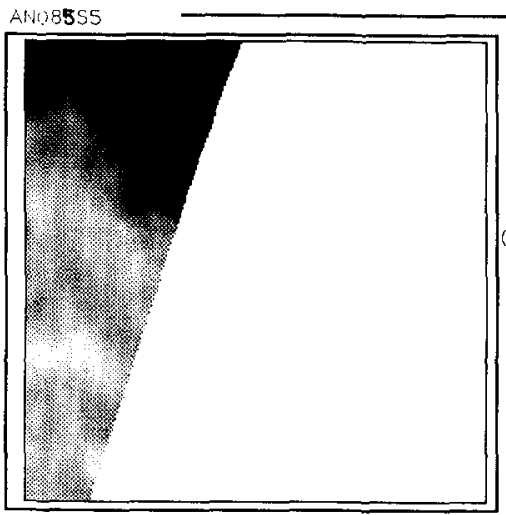

AN 09755

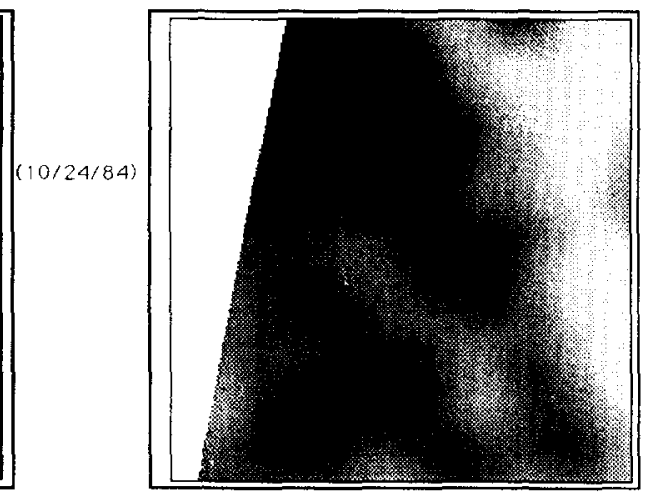

ANCIS5 L I;

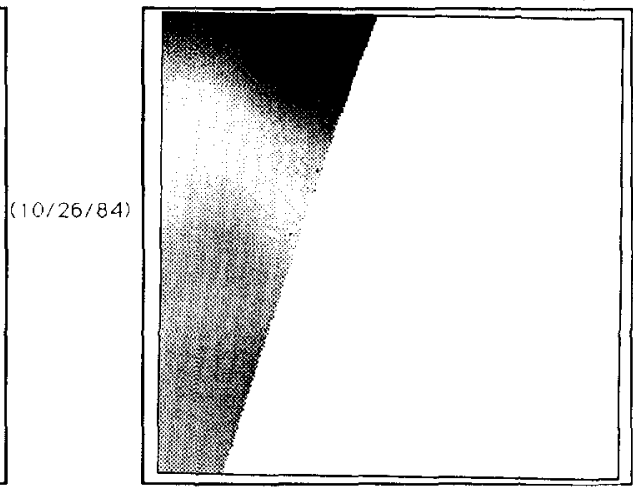

ANOS: $: 1$;

Fig. 9. (a) $37 \mathrm{GHz}$ and FI image sequences for a 6-day period in October. Midnight data. (b) $37 \mathrm{GHz}$ and $\mathrm{FI}$ image sequences for a 6-day period in October. Noon data. 
(b)
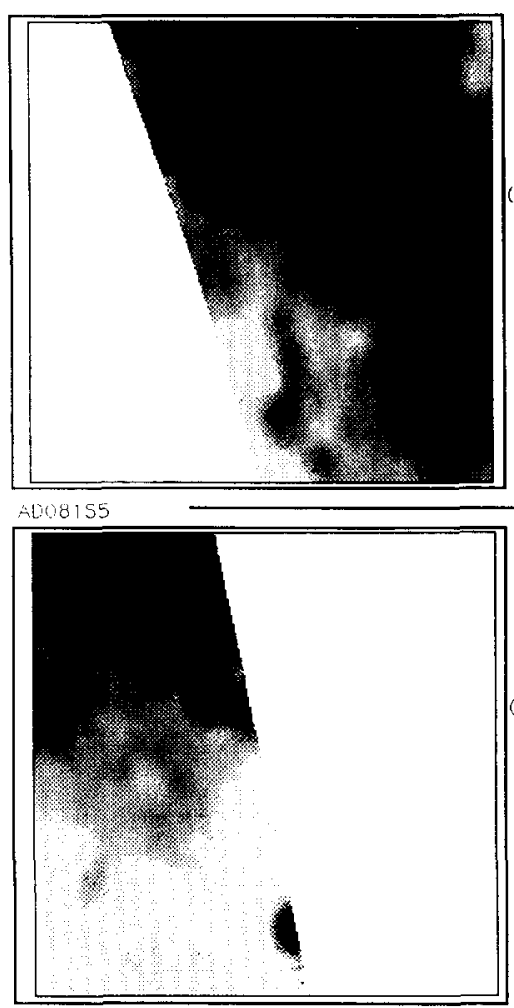

$41+1955$

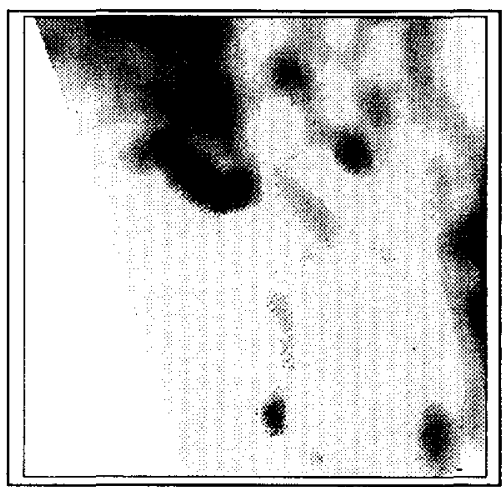

A. 108755
NOON

FREEZE INDICATOR

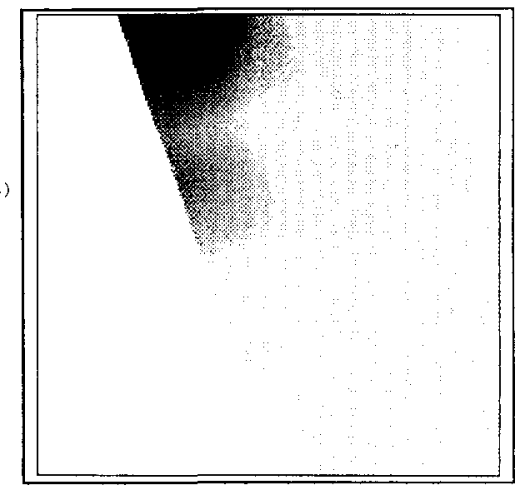

A

$10,22 / 84)$

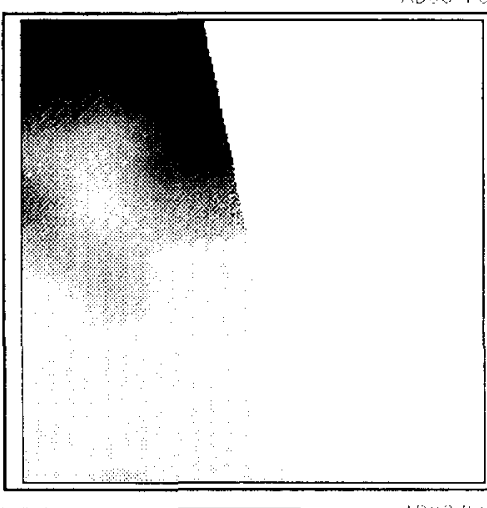

$(10 / 24 / 84)$

$(10 / 26 / 84)$

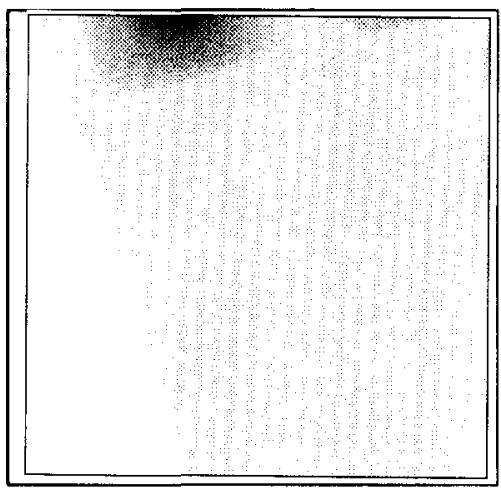

Alous : :

Fig. 9 contd. 
(a)

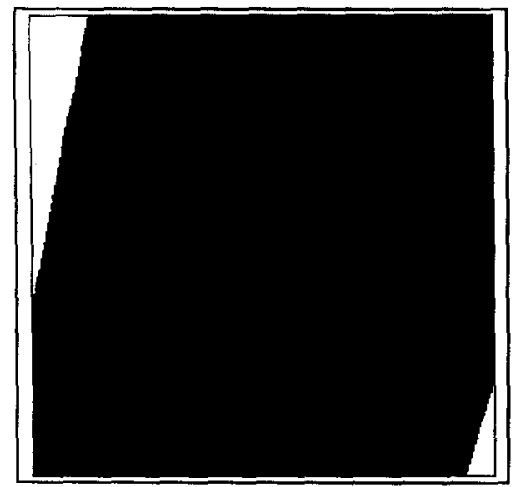

A 12555

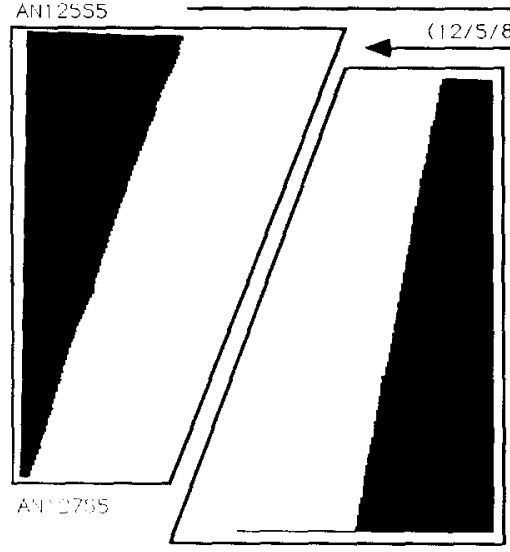

AN 12955

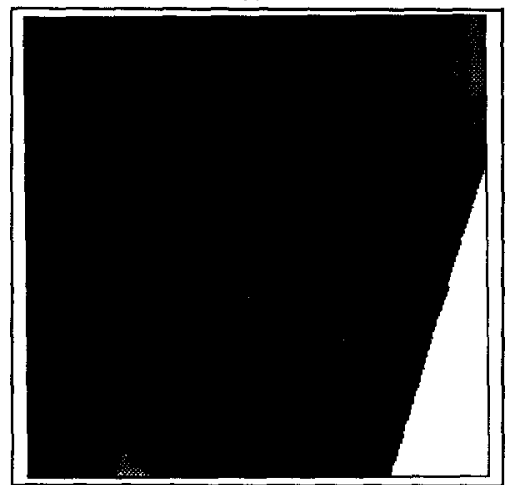

Ar: 3155
MIDNIGHT

$(12 / 3 / 84)$

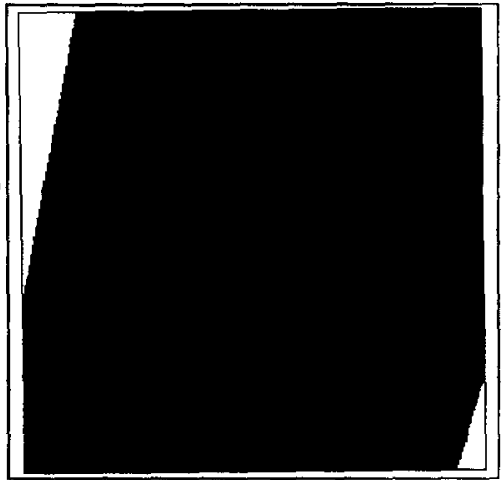

A.t.:.t,

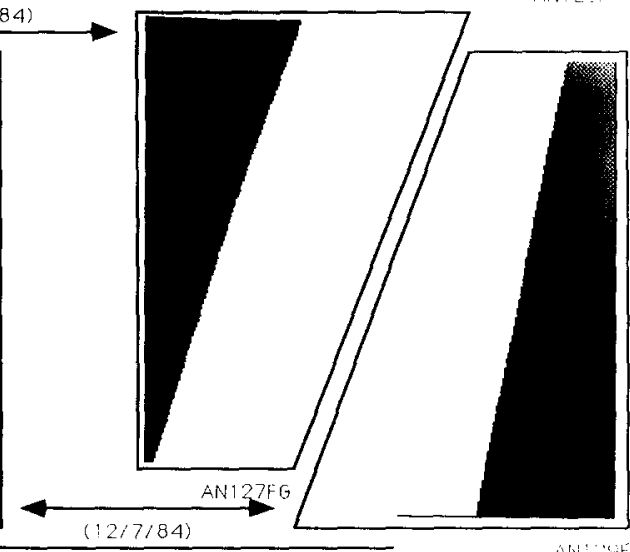

$(1277184)$

$12 / 9 / 84)$

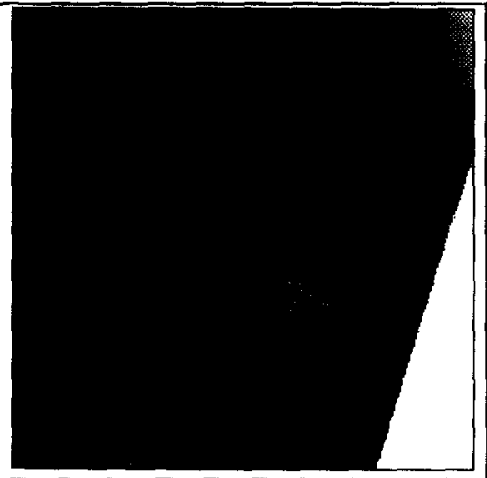

aN: \% :

Fig. 10. (a) $37 \mathrm{GHz}$ and Fl image sequences for a 6-day period in December. Midnight data. (b) $37 \mathrm{GHz}$ and FI image sequences for a 6-day period in December. The jagged white lines in the noon 5 December 1984 image are caused by missing data. Noon data. 
(b) 37 GHZ RADIOBRIGHTNESS
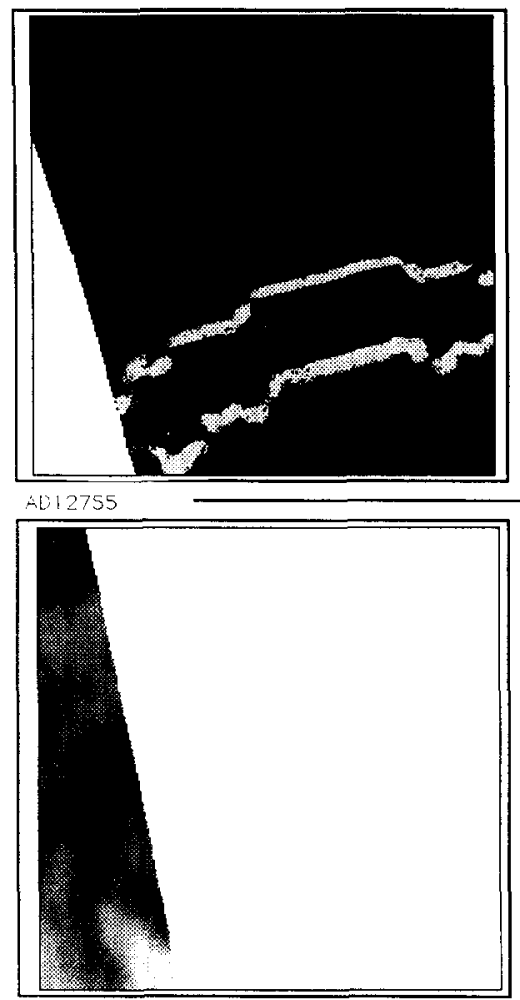

ALi 1295

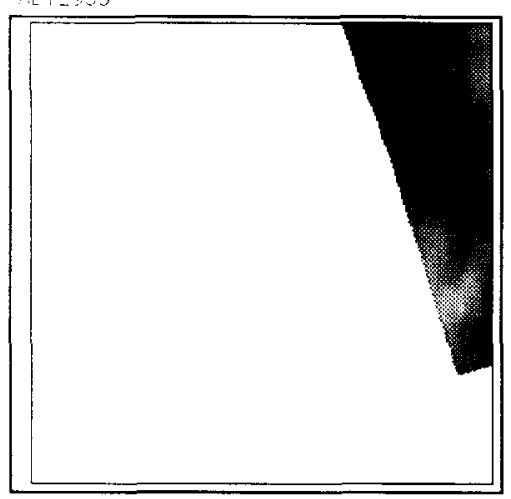

A. 13155
NOON

(12/3/84)
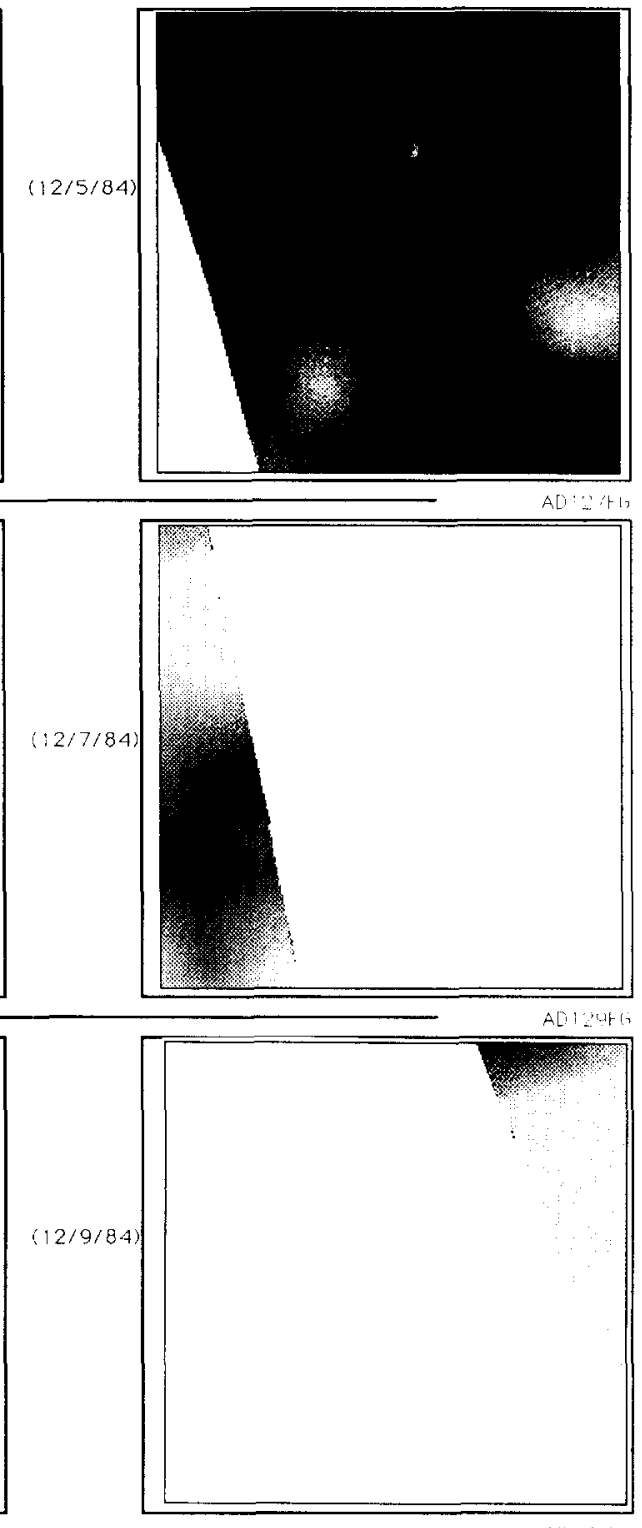

Fig. 10 contd. 
midnight and noon for 6-day periods in September, October and December (Figs. 8-10) SMMR coverage is based on a 48-h cycle midnight (00:00 local hours on the date shown), noon (12:00 h on the same date), and then midnight again $36 \mathrm{~h}$ later. However, orbit precession causes gaps in the cycle and variations in the coverage footprint. Within these constraints, our objective was to observe, if possible weather dynamics reflected in the FI images.

The $37 \mathrm{GHz}$ sequence beginning on 16 September (Fig. 8 and Table 2) shows the moist area associated with the Missouri River, Sakakawea and Devils Lakes in ND, and the Missouri River and Lake Oahe in SD. Rain during the night of 21 September appears as a regional darkening of the $37 \mathrm{GHz}$ image for midnight on 22 September. It should be noted that the rain is not picked up in the FI image.

The October sequence (Fig. 9) is dominated by a cold front passing through the area from the northwest with rain and snow beginning on 19 October. The region is warmer and drier by 26 October. The moisture pattern dominates the $37 \mathrm{GHz}$ image, but only the apparent freeze pattern, which generally lags the cold front, is shown in the FI image. Note that strong freeze indications follow the cold front but weaken in the south with warming on 26 October.

The December sequence (Fig. 10) is characterized by cold temperatures and snow from 2 to 5 December followed by daytime warming into the $40 \mathrm{~s}$ (and even $58^{\circ} \mathrm{F}$ at Rapid City, SD) by 9 December. The FI images reflect this general coldness, but also show daytime thawing toward the end of the period.

\section{CONCLUSIONS}

FI images based upon a preliminary, 2-parameter discriminant, $37 \mathrm{GHz}$ radiobrightness and $10.7,18$ and $37 \mathrm{GHz}$ spectral gradient show relatively good correlation with the expected state of moisture in northern Great Plains soils during the fall of 1984 . The discriminant is preliminary in the sense that both theoretical and experimental work are required to exploit fully the diurnal radiobrightness signatures and to determine an optimum classifier. The concept underlying the preliminary discriminant is that frozen soil will exhibit volume scatter darkening at shorter microwave wavelengths much like the effect observed in dry snow. Few other surface phenomena cause negative microwave spectral gradients.

FI images based upon SMMR data effectively map temporal variations in the freeze/thaw pattern for the northern Great Plains at the time scale of days. These patterns are synchronized with weather patterns, but are not identical. We intend to expand our test data set to include several complete seasons. The product would be, in essence, a movie of freeze/thaw patterns as weather fronts sweep through the Great Plains throughout several seasons. The devel- 
opment of these data from SMMR archives should provide one aspect of a meso-scale climatic baseline for the region.

\section{REFERENCES}

Burke, W.J., Schmugge, T. and Paris, J.F., 1979. Comparison of 2.8- and 21-cm microwave radiometer observations over soils with emission model calculations. J. Geophys. Res.. 84: 287-294.

Camillo, P.J. and Schmugge, T.J., 1984. Correlating rainfall with remotely sensed microwave radiation using physically based models. IEEE Trans. Geosci. Remote Sensing, GE-22, pp. 415-423.

Edgerton, A.T., Stogryn, A. and Poe, G., 1971. Microwave Radiometric Investigations of Snowpacks. Final Rep. 1285R-4 of Contract 14-08-001-11828 between Aerojet-General Corp., El Monte, CA, and the U.S. Geological Survey, pp. 4.1-4.31.

England, A.W., 1974. The effect upon microwave emissivity of volume scattering in snow, in ice, and in frozen soil. Proc. URSI Special Meeting on Microwave Scattering and Emission from the Earth, Berne, Switzerland, 23-26 September 1974, pp. 273-287.

England, A.W., 1975. Thermal microwave emission from a scattering layer. J. Geophys. Res., 80: 4484-4496.

England, A.W., 1976. Relative influence upon microwave emissivity of fine-scale stratigraphy, internal scattering, and dielectric properties. Pageoph., 114:287-299.

England, A.W., 1977. Microwave brightness spectra of layered media. Geophysics, 42: 514521.

Grody, N.C., 1988. Surface identification using satellite microwave radiometers. IEEE Trans. Geosci. Remote Sensing, 26: 850-859.

Hoekstra, P. and Delaney, A., 1974. Dielectric properties of soils at UHF and microwave frequencies. J. Geophys. Res., 79: 699-1708.

Moik, J., 1980. Digital Processing of Remotely Sensed Images. NASA Publication, NASA SP431.

Schmugge, T.J., 1983. Remote sensing of soil moisture: Recent advances. IEEE Trans. Geosci. Remote Sensing, GE-21, pp. 336-344.

Schmugge, T.J., 1987. Remote sensing applications in hydrology. Rev. Geophys., 25: 148-152.

Schmugge, T.J., O'Neill, P.E. and Wang, J.R., 1986. Passive microwave soil moisture research. IEEE Trans. Geosci. Remote Sensing, GE-24: pp. 12-22.

Ulaby, F.T., Moore, R.K. and Fung, A.K., 1981. Microwave Remote Sensing, Active and Passive. Addison-Wesley, Reading, MA, pp. 186-255.

Wang, J.R., Schmugge, T.J., Gould, W.I., Glazar, W.S. and Fuchs, J.E., 1982. A multifrequency radiometric measurement of soil moisture content over bare and vegetated fields. Geophys. Res. Lett., 9: 416-419.

Zuerndorfer, B., England, A.W. and Wakefield, G.H., 1989. The radiobrightness of freezing terrain. Proc. of IGARSS '89, Vancouver, B.C., 10-14 July, pp. 2748-2751. 